\title{
Vitamin D Incorporation in Foods: Formulation Strategies, Stability, and Bioaccessibility as Affected by the Food Matrix
}

\author{
Vera Lavelli * (1), Paolo D’Incecco (1) and Luisa Pellegrino (1) \\ Department of Food, Environmental and Nutritional Sciences (DeFENS), University of Milan, 20133 Milan, Italy; \\ paolo.dincecco@unimi.it (P.D.); luisa.pellegrino@unimi.it (L.P.) \\ * Correspondence: vera.lavelli@unimi.it; Tel.: +39-02-50319172
}

check for

updates

Citation: Lavelli, V.; D'Incecco, P.;

Pellegrino, L. Vitamin D

Incorporation in Foods: Formulation

Strategies, Stability, and

Bioaccessibility as Affected by the

Food Matrix. Foods 2021, 10, 1989.

https://doi.org/10.3390/

foods10091989

Academic Editors: Elsa M. Gonçalves and Marta Abreu

Received: 13 July 2021

Accepted: 23 August 2021

Published: 25 August 2021

Publisher's Note: MDPI stays neutral with regard to jurisdictional claims in published maps and institutional affiliations.

Copyright: (c) 2021 by the authors. Licensee MDPI, Basel, Switzerland. This article is an open access article distributed under the terms and conditions of the Creative Commons Attribution (CC BY) license (https:// creativecommons.org/licenses/by/ $4.0 /)$.

\begin{abstract}
Inadequate intake of vitamin D is a global health issue related to severe diseases, mainly involving subjects with dark skin pigmentation, patients affected by malnutrition, malabsorption syndromes, or obesity, and elderly people. Some foods fortified with vitamin D have been tested in vivo, but fortification strategies with a global outreach are still lacking. This review is focused on food fortification with vitamin D, with the aim to collect information on (a) formulation strategies; (b) stability during processing and storage; and (c) in vitro bioaccessibility. Approaches to add vitamin D to various foods were analyzed, including the use of free vitamin D, vitamin D loaded in simple and double nanoemulsions, liposomes, casein micelles, and protein nanocapsules. Numerous studies were reviewed to elucidate the impact of food technologies on vitamin D's stability, and mechanisms that lead to degradation were identified-namely, acid-catalyzed isomerization, radicalinduced oxidation, and photo-oxidation. There is, however, a lack of kinetic data that allow for the prediction of vitamin D's stability under industrial processing conditions. The roles that lipids, proteins, fibers, and antioxidants play in vitamin bioaccessibility have been clarified in various studies, while future needs include the design of specific food matrices that simultaneously achieve a balance between the long-term stability, bioaccessibility and, ultimately, in vivo functionality of vitamin D.
\end{abstract}

Keywords: vitamin D; nanoemulsions; liposomes; casein micelles; protein nanocapsules; fortification; stability; bioaccessibility

\section{Introduction}

Vitamin D performs essential functions for human health, and concerns about its inadequate dietary intake have been expressed worldwide [1,2]. Vitamin D has two prevalent forms, i.e., cholecalciferol (vitamin $\mathrm{D}_{3}$ ) and ergocalciferol (vitamin $\mathrm{D}_{2}$ ). These vitamers are formed through the UV conversion of precursor compounds-namely, 7 dehydrocholesterol present in vertebrates for vitamin $\mathrm{D}_{3}$, and ergosterol present in fungi and some invertebrates for vitamin $\mathrm{D}_{2}$. The equivalence of the in vivo effectiveness of vitamin $D_{2}$ and vitamin $D_{3}$ has not been fully elucidated. In fact, some studies showed the same biological activity for both vitamers [3,4], while other studies suggested a higher bioavailability for vitamin $\mathrm{D}_{3}$ than for vitamin $\mathrm{D}_{2}$ [5-7]. Upon ingestion, both vitamin $\mathrm{D}_{2}$ and vitamin $\mathrm{D}_{3}$ are converted into the same biologically active form, i.e., 1,25-dihydroxyvitamin $\mathrm{D}(1,25(\mathrm{OH}) 2 \mathrm{D})$. This latter compound binds to a nuclear receptor and modulates gene expression. Interestingly, the vitamin $\mathrm{D}$ receptor was found to be present in most cells in the body, and this finding supports the involvement of vitamin $\mathrm{D}$ in the prevention of multiple diseases [8,9]. In fact, vitamin D performs a fundamental role in the maintenance of skeletal calcium and phosphate balance, thus preventing rickets in children and osteomalacia, osteoporosis, and bone fractures in adults. Moreover, it has been associated with protection from the risk of common cancers, autoimmune diseases, hypertension, and infectious diseases [2]. The recommended dietary intake of vitamin D is 10, 15, and $20 \mu \mathrm{g} / \mathrm{d}$ for 
infants ( $<1$ year), subjects aged $1-70$ years, and subjects aged $>70$ years, respectively [10]. Observational studies led to the conclusion that vitamin D supplementation should be 2-3 times higher for obese subjects and 1.5 times higher for overweight subjects, relative to normal-weight subjects [11]. Moreover, for people at risk of vitamin D deficiency, the recommended daily dose of vitamin $\mathrm{D}$ is $50 \mu \mathrm{g} / \mathrm{d}$ or higher, depending on age [10]. The recognized biomarker for vitamin $\mathrm{D}$ status is serum 25-hydroxyvitamin $\mathrm{D}(25(\mathrm{OH}) \mathrm{D})$ level. Some panels of experts indicate that vitamin D deficiency corresponds to a $(25(\mathrm{OH}) \mathrm{D})$ level below $50 \mathrm{nmol} / \mathrm{L}$, vitamin D insufficiency to a level between 50 and $75 \mathrm{nmol} / \mathrm{L}$, and vitamin D toxicity to levels above $500 \mathrm{nmol} / \mathrm{L}$ [10]. However, other panels of experts indicated that the cutoff below which the risk of clinical vitamin $\mathrm{D}$ deficiency increases corresponds to a serum level of $25(\mathrm{OH}) \mathrm{D}<30 \mathrm{nmol} / \mathrm{L}$ [12]. Populations at risk of vitamin D deficiency include subjects with dark skin pigmentation, subjects affected by malnutrition, malabsorption syndromes, or obesity, and elderly people [9]. Vitamin D insufficiency is also common. In fact, a survey throughout Europe has shown that the intake of vitamin D is inadequate for $77-100 \%$ of adults (19-64 years old) and for $55-100 \%$ of elderly adults ( $>64$ years old) [13]. Compared to the USA, Vitamin D intake from food in Europe is lower [14], which can be attributed to the higher availability of foods fortified with vitamin $\mathrm{D}$ in the USA than in Europe [1]. Indeed, food fortification with vitamin D is considered a fundamental strategy to fight vitamin D malnutrition and its associated diseases $[1,3,15]$.

Foods fortified with vitamin D-especially bread and dairy products-have been assessed in vivo for their efficacy in raising the level of $25(\mathrm{OH}) \mathrm{D}$ and improving health in different target populations (Table 1). In both low-fiber white bread and high-fiber sourdough rye bread, fortification with a water-dispersible form of vitamin $\mathrm{D}_{3}$ providing approximately $10 \mu \mathrm{g} / \mathrm{d}$ was as effective as vitamin $D_{3}$ supplements in increasing serum $25(\mathrm{OH}) \mathrm{D}$ concentration in healthy women aged $25-45$ years [16]. The production of bread with UV-irradiated yeast as a source of $25 \mu \mathrm{g} / \mathrm{d}$ of vitamin $\mathrm{D}_{2}$ did not affect serum $25(\mathrm{OH}) \mathrm{D}$ concentration in healthy women aged 20-37 years, while supplements of both vitamin $\mathrm{D}_{2}$ and vitamin $\mathrm{D}_{3}$ resulted in a positive effect [17]. Conversely, vitamin $\mathrm{D}_{2}$ from UVirradiated mushroom formulated in a soup was as effective as vitamin $\mathrm{D}_{2}$ supplements in increasing serum $25(\mathrm{OH}) \mathrm{D}$ concentration in healthy subjects younger than 45 years, but the amount provided was high, equal to $700 \mu \mathrm{g} / \mathrm{d}$ [18]. In $\mathrm{Ca}^{++}$-enriched orange juice, water-dispersible forms of either vitamin $D_{2}$ or vitamin $D_{3}$ in a dose of $25 \mu \mathrm{g} / \mathrm{d}$ were equally bioavailable as the respective supplements in adult subjects aged 18-84 years [4]. The impact of $\mathrm{Ca}^{++}$enrichment along with vitamin $\mathrm{D}_{2}$ was not investigated, because a control without $\mathrm{Ca}^{++}$addition was not included [4].

Reduced-fat milk enriched with $\mathrm{Ca}^{++}$was an effective matrix for vitamin $\mathrm{D}_{3}$ fortification, when administered at a level of $20 \mu \mathrm{g} / \mathrm{d}$ to healthy male subjects aged $50-87$ years, causing increased serum $25(\mathrm{OH}) \mathrm{D}$ concentration and reduced bone loss, but no information was provided on the incorporated form of vitamin $\mathrm{D}_{3}$ [19]. In a subsequent study, fortification of $\mathrm{Ca}^{++}$-enriched milk with a non-specified form of vitamin $\mathrm{D}_{3}$, as well as fortification of $\mathrm{Ca}^{++}$-enriched orange juice, were designed for healthy children aged 9-12 years, and were found to be effective in increasing serum $25(\mathrm{OH})$ concentration, while serum osteocalcin and intact parathyroid hormone were not affected [20]. However, in these latter two studies, foods enriched in $\mathrm{Ca}^{++}$and vitamin $\mathrm{D}$ were also considered, but the impact of $\mathrm{Ca}^{++}$enrichment was not investigated $[19,20]$.

Contradictory results were obtained by applying a water-dispersible form of vitamin $\mathrm{D}_{3}$ in cheese, but the supplied amounts were different [21,22]. In fact, in one study involving healthy, $\geq 60$-year-old subjects, no effects on $25(\mathrm{OH}) \mathrm{D}$, parathyroid hormone, or osteocalcin serum concentrations were observed upon the consumption of vitamin- $\mathrm{D}_{3}$-fortified cheese supplying $15 \mu \mathrm{g} / \mathrm{d}$ [21], while in another study involving healthy subjects aged 18-60 years, an increase in serum $25(\mathrm{OH}) \mathrm{D}$ concentration was observed along with a decreased serum parathyroid hormone upon consumption of either regular Cheddar cheese (obtained from milk having 3.8\% fat content) or reduced-fat cheese (obtained from skim milk having $0.8 \%$ fat content), both supplying $100 \mu \mathrm{g} / \mathrm{d}$ of vitamin $\mathrm{D}_{3}$ [22]. 
Table 1. In vivo studies on the effects of vitamin-D-fortified foods.

\begin{tabular}{|c|c|c|c|c|}
\hline Fortified Food & Subjects and Duration & $\begin{array}{l}\text { Dose } \\
(\mu \mathrm{g} / \mathrm{d})\end{array}$ & Outcome & Ref. \\
\hline $\begin{array}{l}\text { Water-dispersible vitamin } \mathrm{D}_{3} \\
\text { in low-fiber wheat bread }\end{array}$ & \multirow{2}{*}{$\begin{array}{l}25-45 \text { years, healthy women } \\
n=41,1 \text { month }\end{array}$} & 10.8 & \multirow{2}{*}{$\begin{array}{l}\text { Both vitamin- } \mathrm{D}_{3} \text {-fortified breads } \\
\text { increased serum } 25(\mathrm{OH}) \mathrm{D} \text { as } \\
\text { effectively as vitamin } \\
\mathrm{D}_{3} \text { supplement. }\end{array}$} & \multirow{2}{*}[16]{} \\
\hline $\begin{array}{c}\text { Water-dispersible vitamin } D_{3} \\
\text { in high-fiber sourdough rye bread }\end{array}$ & & 12.3 & & \\
\hline $\begin{array}{l}\text { Vitamin } \mathrm{D}_{2} \text { from UV-irradiated yeast } \\
\text { in bread }\end{array}$ & $\begin{array}{l}20-37 \text { years, healthy women } \\
n=33,2 \text { months }\end{array}$ & 25 & $\begin{array}{l}\text { Vitamin } \mathrm{D}_{2} \text { from UV-irradiated } \\
\text { yeast in bread did not raise serum } \\
25(\mathrm{OH}) \mathrm{D} \text {. }\end{array}$ & [17] \\
\hline $\begin{array}{l}\text { Vitamin } \mathrm{D}_{2} \text { from UV-irradiated } \\
\text { mushrooms in soup }\end{array}$ & $\begin{array}{l}<45 \text { years, healthy } \\
n=26,1 \text { month }\end{array}$ & 700 & $\begin{array}{l}\text { Vitamin- } \mathrm{D}_{2} \text {-fortified soup } \\
\text { increased serum } 25(\mathrm{OH}) \mathrm{D} \text { as } \\
\text { effectively as vitamin } \mathrm{D}_{2} \\
\text { supplement. }\end{array}$ & [18] \\
\hline $\begin{array}{l}\text { Water-dispersible vitamin } \mathrm{D}_{3} \\
\text { in } \mathrm{Ca}^{++} \text {-enriched orange juice } \\
\left(\mathrm{Ca}^{++} \text {dose: } 350 \mathrm{mg} / \mathrm{d}\right)\end{array}$ & \multirow{2}{*}{$\begin{array}{l}\text { 18-84 years, healthy } \\
n=105,3 \text { months }\end{array}$} & \multirow{2}{*}{25} & \multirow{2}{*}{$\begin{array}{c}\text { Vitamin } \mathrm{D}_{2} \text { and vitamin } \mathrm{D}_{3} \text { were } \\
\text { equally bioavailable in } \\
\mathrm{Ca}^{++} \text {-enriched orange juice } \\
\text { and capsules. }\end{array}$} & \multirow{2}{*}{ [4] } \\
\hline $\begin{array}{l}\text { Water-dispersible vitamin } \mathrm{D}_{2} \\
\text { in } \mathrm{Ca}^{++} \text {-enriched orange juice } \\
\left(\mathrm{Ca}^{++} \text {dose: } 350 \mathrm{mg} / \mathrm{d}\right)\end{array}$ & & & & \\
\hline $\begin{array}{c}\text { Vitamin } \mathrm{D}_{3} \text { non-specified } \\
\text { in } \mathrm{Ca}^{++} \text {-enriched reduced-fat milk } \\
\left(\mathrm{Ca}^{++} \text {dose: } 1000 \mathrm{mg} / \mathrm{d}\right)\end{array}$ & $\begin{array}{c}50-87 \text { years, healthy men } \\
n=149,2 \text { years }\end{array}$ & 20 & $\begin{array}{l}\text { Vitamin- } \mathrm{D}_{3} \text { - and } \mathrm{Ca}^{++} \text {-fortified } \\
\text { milk increased serum } 25(\mathrm{OH}) \mathrm{D} \\
\text { and reduced bone loss. }\end{array}$ & [19] \\
\hline $\begin{array}{c}\text { Vitamin } \mathrm{D}_{3} \text { non-specified } \\
\text { in } \mathrm{Ca}^{++} \text {-enriched orange juice } \\
\left(\mathrm{Ca}^{++} \text {dose: } 500 \mathrm{mg} / \mathrm{d}\right)\end{array}$ & \multirow{2}{*}{$\begin{array}{l}\text { 9-12 years, healthy } \\
n=410,3 \text { months }\end{array}$} & \multirow{2}{*}{2.5} & \multirow{2}{*}{$\begin{array}{l}\text { Vitamin- } \mathrm{D}_{3} \text {-fortified milk and } \\
\text { orange juice increased serum } \\
\text { 25(OH). Serum OC and PHT were } \\
\text { not affected. }\end{array}$} & \multirow[b]{2}{*}[20]{} \\
\hline $\begin{array}{l}\text { Vitamin } \mathrm{D}_{3} \text { non-specified } \\
\text { in } \mathrm{Ca}^{++} \text {-enriched milk } \\
\left(\mathrm{Ca}^{++} \text {dose: } 500 \mathrm{mg} / \mathrm{d}\right)\end{array}$ & & & & \\
\hline $\begin{array}{l}\text { Water-dispersible vitamin } \mathrm{D}_{3} \\
\text { in cheese }\end{array}$ & $\begin{array}{l}\geq 60 \text { years, healthy } \\
n=110,2 \text { months }\end{array}$ & 15 & $\begin{array}{l}\text { Vitamin- } \mathrm{D}_{3} \text {-fortified cheese had no } \\
\text { effect on serum } 25(\mathrm{OH}) \mathrm{D}, \mathrm{OC} \\
\text { and PHT. }\end{array}$ & [21] \\
\hline $\begin{array}{l}\text { Water-dispersible vitamin } \mathrm{D}_{3} \\
\text { in Cheddar cheese }\end{array}$ & $\begin{array}{l}18-60 \text { years, healthy } \\
n=30,2 \text { months }\end{array}$ & 100 * & $\begin{array}{c}\text { Both vitamin- } \mathrm{D}_{3} \text {-fortified cheeses } \\
\text { increased serum } 25(\mathrm{OH}) \mathrm{D} \text { and } \\
\text { decreased serum } \mathrm{PHT} \text { as vitamin } \\
\mathrm{D}_{3} \text { supplement }\end{array}$ & [22] \\
\hline $\begin{array}{l}\text { Vitamin } \mathrm{D}_{3} \text { non-specified } \\
\text { in regular yogurt } \\
\left(\mathrm{Ca}^{++} \text {dose: } 150 \mathrm{mg} / \mathrm{d}\right)\end{array}$ & \multirow{2}{*}{$\begin{array}{l}30-60 \text { years, diabetic } \\
n=90,3 \text { months }\end{array}$} & \multirow[b]{2}{*}{25} & \multirow{2}{*}{$\begin{array}{l}\text { Both vitamin- } \mathrm{D}_{3} \text {-fortified regular } \\
\text { yogurt and } \mathrm{Ca}^{++} \text {-enriched yogurt } \\
\text { increased serum } 25(\mathrm{OH}) \mathrm{D} \text { and } \\
\text { improved glycemic status. }\end{array}$} & \multirow[b]{2}{*}{ [23] } \\
\hline $\begin{array}{c}\text { Vitamin } \mathrm{D}_{3} \text { non-specified } \\
\text { in } \mathrm{Ca}^{++} \text {enriched yogurt } \\
\left(\mathrm{Ca}^{++} \text {dose: } 250 \mathrm{mg} / \mathrm{d}\right) \\
\end{array}$ & & & & \\
\hline $\begin{array}{l}\text { Vitamin } \mathrm{D}_{3} \text { non-specified } \\
\text { in } \mathrm{Ca}^{++} \text {enriched yogurt } \\
\left(\mathrm{Ca}^{++} \text {dose: } 800 \mathrm{mg} / \mathrm{d}\right)\end{array}$ & $\begin{array}{l}\geq 65 \text { years, healthy women } \\
\quad n=20,3 \text { months }\end{array}$ & 10 & $\begin{array}{l}\text { Vitamin- } \mathrm{D}_{3} \text {-fortified yogurt } \\
\text { increased serum } 25(\mathrm{OH}) \mathrm{D} \text {, and } \\
\text { maintained cognitive performance. }\end{array}$ & [24] \\
\hline $\begin{array}{l}\text { Water-dispersible vitamin } \mathrm{D}_{3} \\
\text { in yogurt }\end{array}$ & $\begin{array}{l}37-47 \text { years, pre-diabetic } \\
n=60,3 \text { months }\end{array}$ & 25 & $\begin{array}{c}\text { Vitamin- } \mathrm{D}_{3} \text {-fortified yogurt } \\
\text { increased serum } 25(\mathrm{OH}) \mathrm{D} \text { as } \\
\text { effectively as vitamin } \mathrm{D}_{3} \\
\text { supplement, and improved serum } \\
\text { lipid profile. }\end{array}$ & [25] \\
\hline $\begin{array}{l}\text { Vitamin } \mathrm{D}_{3} \text { in casein micelles } \\
\text { in low-fat yogurt }\end{array}$ & \multirow{2}{*}{$\begin{array}{l}18-61 \text { years, healthy } \\
n=87, \text { single intake }\end{array}$} & \multirow[b]{2}{*}{1250} & \multirow{2}{*}{$\begin{array}{l}\text { Both vitamin } \mathrm{D}_{3} \text { carriers in yogurt } \\
\text { increased serum } 25(\mathrm{OH}) \mathrm{D} \text {. }\end{array}$} & \multirow[b]{2}{*}{ [26] } \\
\hline $\begin{array}{l}\text { Vitamin } \mathrm{D}_{3} \text { in emulsion } \\
\text { in low-fat yogurt }\end{array}$ & & & & \\
\hline
\end{tabular}

*: Equivalent to a daily dose (fortified food was ingested in one weekly dose); PHT: parathyroid hormone; OC: osteocalcin.

Various approaches have been applied for yogurt fortification with vitamin $\mathrm{D}_{3}$. In one study, a non-specified form of vitamin $\mathrm{D}_{3}$ was added alone or in combination with $\mathrm{Ca}^{++}$in yogurt, and both formulations supplying $25 \mu \mathrm{g} / \mathrm{d}$ were effective in raising serum $25(\mathrm{OH}) \mathrm{D}$ levels and improving the glycemic status of diabetic subjects aged 30-60 years. 
Hence, the combined effect of $\mathrm{Ca}^{++}$and vitamin $\mathrm{D}$ enrichment of the food matrix seemed not to be relevant [23]. Positive effects on serum 25(OH)D level and in the maintenance of cognitive performance were also observed upon consumption of yogurt enriched with $\mathrm{Ca}^{++}$and $10 \mu \mathrm{g} / \mathrm{d}$ of a non-specified form of vitamin $\mathrm{D}_{3}$ by a population of healthy elderly women ( $\geq 65$ years), while vitamin $\mathrm{D}$ enrichment of yogurt with regular $\mathrm{Ca}^{++}$content was not considered [24]. In another approach, the water-dispersible form of vitamin $\mathrm{D}_{3}$ was used to fortify yogurt, and proved to be effective in increasing serum $25(\mathrm{OH}) \mathrm{D}$ levels and improving the serum lipid profiles of pre-diabetic subjects aged 37-47 years [25], when administered at a dose of $25 \mu \mathrm{g} / \mathrm{d}$. Casein micelles or polysorbate/Tween- 80 emulsions were designed as carriers to formulate vitamin $\mathrm{D}_{3}$ in low-fat yogurt, and both formulations were found to be effective in raising serum $25(\mathrm{OH}) \mathrm{D}$ in healthy subjects aged 18-61 years, but the dose administered was equal to $1250 \mu \mathrm{g} / \mathrm{d}$ [26]—well above the recommended daily dose.

The above-reported in vivo studies cannot be compared because of the different target populations involved, daily doses administered, and durations of the interventions. However, in general they support the efficacy of fortification of various food matrices as a strategy to manage inadequate vitamin $\mathrm{D}$ intake. Nevertheless, in order to apply a vitamin D fortification strategy, further issues need to be considered. Firstly, the form in which vitamin D was administered is generally unknown or lacks relevant information, and the dosage applied was higher than the recommended daily dose. Hence, no information on the cost-effectiveness of the fortification strategy can be derived. Moreover, in most in vivo studies, food fortification was performed by adding vitamin $\mathrm{D}$ to the processed product just before the administration, while no information is provided on vitamin D stability when addition is carried out prior to food processing, packaging, and long-term storage. In vitro modelling studies can provide in-depth information on vitamin D's stability and bioaccessibility. Hence, this review article is focused on food fortification with vitamin $\mathrm{D}$, with the aim to collect information on (a) the formulation strategies of vitamin D in foods; (b) the stability of vitamin D in fortified foods during processing and storage; and (c) the in vitro bioaccessibility of vitamin $\mathrm{D}$ from the fortified foods. The ultimate aim of this study is to support the design of an efficient technology for the vitamin $\mathrm{D}$ fortification of foods.

\section{Vitamin D Fortified Foods: Formulation Strategies}

Vitamin $\mathrm{D}_{3}$ obtained at the industrial level is generally used for food fortification. The free form of vitamin $\mathrm{D}_{3}$ has likely been incorporated in the food matrices evaluated in some in vivo studies, although this is not specifically indicated $[19,20,23,24]$. Free vitamin $D_{3}$ has also been used in various in vitro studies [27-33], while free vitamin $D_{2}$ has been considered in only a few in vitro studies [31].

Irradiated yeasts and mushrooms have been used directly as a source of vitamin $\mathrm{D}_{2}$ in fortified foods for in vivo $[17,18]$ and in vitro studies [30]. The application of the unprotected compound in food formulation has the major drawbacks of non-homogeneous dispersion in the matrix, uncontrolled stability, and fast release. Moreover, the application of vitamin $\mathrm{D}_{2}$ entrapped in yeast cells was not effective in vivo [17], while that entrapped in mushrooms was effective in vivo only at very high dosages [18].

Vitamin D is a large sterol molecule. Considering its low water solubility and susceptibility to oxidative or heat degradation, suitable delivery systems have been studied for food fortification (Table 2). In brief, water-dispersible vitamin premixes-often containing an emulsifier-and oil-based systems have been proposed, depending on the characteristics of the target food. A commercial water-soluble form of vitamin D containing propylene glycol and polysorbate 80 (Vitex-D, Kingsway Chocolate Co. Ltd., Bunge Foods, Mississauga, ON, Canada) was used in one in vivo [22] and in some in vitro studies [34,35], but no information was provided on the formulation characteristics, such as its particle size distribution, which affects its bioaccessibility [36]. Other in vivo [4,16,20,25] or in vitro [37-39] studies 
reported the use of water-dispersible forms of vitamin $\mathrm{D}_{3}$ or vitamin $\mathrm{D}_{2}$, but no details were provided on composition or particle size distribution.

A strategy to develop value-added fortified foods is the design of specific nano- or micro-structures (Table 2) that enable the homogeneous distribution of bioactive compounds in the food matrix and improve stability and bioavailability [40]. It is worth noting that nano- and micro-structures can potentially be affected by $\mathrm{pH}$, ionic strength, and heat treatments; hence, it is fundamental to test their stability during food processing [41].

It must be underlined that many of the carrier systems developed for vitamin D delivery look promising, but have not found application at the industrial level so far. This review only focuses on studies including a food product application-namely, lipid-based encapsulation systems [42-50], which were considered in vitro studies, and protein complexes, which were considered in studies performed both in vivo [26] and in vitro [51,52].

Lipid-based encapsulation systems used for food fortification with vitamin $\mathrm{D}$ include oil-in-water $(\mathrm{O} / \mathrm{W})$ nanoemulsions [36,43,45-47]; double water-in-oil-in-water $\left(\mathrm{W}_{1} / \mathrm{O} / \mathrm{W}_{2}\right)$ emulsions [48], and liposomes [50]. All of these structures can be affected by chemical instability due to lipid oxidation and physical instability due to their tendency to phase separation.

$\mathrm{O} / \mathrm{W}$ emulsions are structures with a lipophilic core where a lipophilic bioactive compound is entrapped, a hydrophilic shell (aqueous phase), and an amphiphilic interface consisting of the emulsifier/surfactant [53]. Emulsion particles move randomly in the presence of gravitational and Brownian motion forces acting on the droplets in the medium. The main instability processes are flocculation, coalescence, and creaming (or sedimentation), which ultimately lead to complete separation of the two constituting phases. In nanoemulsions, small particle size $(\mathrm{d}<200 \mathrm{~nm})$ creates low susceptibility to gravitational separation due to the dominant Brownian forces [53]. The zeta potential ( $\zeta$-potential) of dispersed oil droplets is also related to emulsion stability, because levels close to zero promote aggregation due to the absence of charge repulsions [54]. In one approach, vitamin $\mathrm{D}_{2}$ emulsions were prepared using corn oil, Tween ${ }^{\circledR} 80$, and phosphate buffer; the amount of vitamin $\mathrm{D}_{2}$ in the oil phase was $50 \mathrm{mg} / 100 \mathrm{~g}$ of oil. By blending these components at a high speed $(10,000 \mathrm{rpm})$, a large emulsion was obtained with a volume-weighted mean diameter of $14.5 \mu \mathrm{m}$ and $\zeta$-potential of $-13.8 \mathrm{mV}$; by passing the large emulsion through a Microfluidizer operating at $6000 \mathrm{psi}$, a medium emulsion was obtained with a volume-weighted mean diameter of $0.53 \mu \mathrm{m}$, and further processing at 15,000 psi resulted in a small emulsion with a volume-weighted mean diameter of $0.11 \mu \mathrm{m}$, with little variation in the $\zeta$-potential [36]. Hence, it was possible to modulate emulsions' nanostructure by varying the energy input of the process. The droplets should have had a low net charge because they were stabilized by a non-ionic surfactant; however, a negative surface charge was observed and attributed to the presence of anionic impurities such as free fatty acids in either the surfactant or the oil phase [36]. The negative charge is expected to inhibit particle aggregation, but the emulsions were not tested in food matrices [36]. In other studies, emulsions were prepared using vitamin $\mathrm{D}_{3}$, flaxseed oil, calcium caseinate, and distilled water, + / - soy lecithin, but the amount of vitamin $\mathrm{D}_{3}$ was not specified. No information was provided on the particle size distribution and $\zeta$-potential; however, physical stability was proven up to $6 \mathrm{~d}$ of storage in the absence of soy lecithin and $15 \mathrm{~d}$ of storage in the presence of soy lecithin; afterwards, the appearance of serum indicated that casein-casein interactions occurred. The adsorption of lecithin to the oil-water interface reduced the interactions between proteins and led to a slow gelation of the emulsion, which was then added to cheese [43]. In another approach, a nanoemulsion of vitamin $\mathrm{D}_{3}$ was created by combining vitamin $\mathrm{D}_{3}$ in corn oil and the surfactant (quillaja saponin) into phosphate buffer solution ( $5 \mathrm{mM}, \mathrm{pH}$ ); the amount of vitamin $\mathrm{D}_{3}$ was $4 \mathrm{~g} / 100 \mathrm{~g}$ of the oil phase. The mean particle diameter of the vitamin-enriched nanoemulsions was $0.14 \mu \mathrm{m}$, the $\mathrm{pH}$ was 4.74 , and the surface charge was negative $(-74.1 \mathrm{mV})$. Due to the strong repulsions between the negative charges on the surface, the nanoemulsion was stable for $7 \mathrm{~d}$ of storage, and was found to be suitable for the fortification of almond milk [47]. 
The $\mathrm{W}_{1} / \mathrm{O} / \mathrm{W}_{2}$ double emulsions have a water-continuous system containing oil droplets with smaller water droplets dispersed within. Double emulsions can simultaneously encapsulate both hydrophobic and hydrophilic compounds. Moreover, double emulsions can have a reduced fat content compared to $\mathrm{O} / \mathrm{W}$ emulsions. As with the single emulsions, double emulsions can undergo flocculation, coalescence, and creaming (or sedimentation); additional instability processes include swelling and rupture of the inner droplets induced by osmotic transport between the two aqueous phases. Hence, there should be a balance between the osmotic pressure of the inner and outer aqueous regions [54]. In one study, $\mathrm{W}_{1} / \mathrm{O} / \mathrm{W}_{2}$ double emulsions containing vitamin $\mathrm{D}_{3}$ were considered; the $\mathrm{W}_{1}$ phase was prepared by adding black chokeberry phenolic extract, folic acid, vitamin $B_{12}$, and vitamin $C$; the $O$ phase consisted of polyglycerol polyricinoleate dispersed in rapeseed oil containing vitamin $\mathrm{D}_{3}$ and vitamin $\mathrm{A}$; and the $\mathrm{W}_{2}$ phase was a milk protein solution. The emulsification process included the preparation of the primary emulsion at a high speed $(15,000 \mathrm{rpm})$ and the preparation of the secondary emulsion at a low speed $(11,000 \mathrm{rpm})$. The amount of vitamin $\mathrm{D}_{3}$ was $7 \mathrm{mg} / 100 \mathrm{~g}$ of oil, and encapsulation efficiency was $98.52 \%$. The resulting $\mathrm{W}_{1} / \mathrm{O} / \mathrm{W}_{2}$ emulsion had a monomodal particle size distribution with a volume moment-weighted mean diameter of $37.65 \mu \mathrm{m}$, and was physically stable for $30 \mathrm{~d}$ [48]. This $\mathrm{W}_{1} / \mathrm{O} / \mathrm{W}_{2}$ double emulsion was then added to yogurt [49].

Liposomes are vesicles with an aqueous core surrounded by one or more amphiphilic molecules—such as polar lipids—that produce a bilayer structure. Hydrophobic substances can be entrapped within the hydrophobic bilayer [55]. Phospholipids are often used as amphiphilic molecules for liposome preparation. The small radius of the curvature of the vesicles generates instability because it disrupts the regular packing of the phospholipid bilayer and imposes constraints on the phospholipid molecules [56]. One of the key parameters for the liposome structure is the transition temperature, where the liposomes lose their ordered packing structure due to melting of the hydrocarbon chains, i.e., they undergo a phase transition from gel to liquid-crystalline. Since natural phospholipids contain hydrocarbon chains that differ in length, phase transition occurs over a wide temperature range. Physical instability of liposomes may arise from merging, which results in increased particle size. Cholesterol is generally added to the phospholipid structure at a volume of over $20 \%$ because it decreases the transition temperature and increases stability [55]. Lipophilic bioactive compounds that are positioned in the lipid bilayer of liposomes, such as vitamin D, can alter the interactions between hydrocarbon chains and, hence, affect bilayer stability. In one study, liposomes loaded with vitamin $\mathrm{D}_{3}$ were added to milk intended for producing fortified cheese, but a commercial liposome premix was used and no information was provided on liposome structure [57]. In another study, liposomes loaded with vitamin $\mathrm{D}_{3}$ were applied in chocolate. Phospholipids, cholesterol, and vitamin $D_{3}$ were used in a 3:1:1 ratio; hence, vitamin $D_{3}$ constituted $20 \mathrm{~g} / 100 \mathrm{~g}$ of the lipid phase. Liposomes were obtained by film dispersion-homogenization. Loading efficiency for vitamin $\mathrm{D}_{3}$ was $68.2 \%$. The resulting liposomes had a monomodal distribution, with an equivalent volume diameter at 50\% cumulative volume of $354.91 \mathrm{~nm}$ and a $\zeta$-potential of $-27.62 \mathrm{mV}$; however, no information on stability was provided [50].

Hydrophobic molecules can also bind to proteins via hydrophobic interactions. A consensus exists on the role of some well-structured proteins, such as milk and soy proteins, as natural nanocarriers of hydrophobic bioactive compounds [58-63]. However, the loading capacity of these structures is likely low, being targeted at the naturally occurring levels of bioactive compounds. Thus, protein-based nanocarriers have been developed as vehicles of vitamin $\mathrm{D}$ at the target levels of fortification in food, with casein being the most frequently involved protein.

Complexation of vitamin $\mathrm{D}$ with whey proteins proved to increase the stability of the vitamin under light and prolonged storage, compared to the free form, but no data obtained on real foods were given $[59,60]$. Compared to native casein micelles, sodium or calcium caseinates are more water soluble, and single casein molecules still maintain the capacity for self-assembly due to their amphiphilic nature. On this basis, the so- 
called reassembled casein micelles (rCMs) have been studied and shown to represent microencapsulation structures that potentially guarantee enhanced stability of vitamin $\mathrm{D}$ during subsequent food processing. The vitamin-loading capacity of rCMs essentially depends on the content of calcium, phosphate, and citrate added in the formulation. By optimizing these parameters, a loading of 1.38-1.46 mg/100 mg casein was achieved for vitamin $\mathrm{D}$, with particles of rCMs showing a monomodal distribution and average volume-weighted particle sizes of 16-19 $\mu \mathrm{m}$, depending on phosphate concentration [61]. However, aqueous suspensions of the rCMs showed $\mathrm{D}(0.5)$ (diameter where $50 \%$ of the particle size distribution is above and $50 \%$ is below) values around $12-13 \mu \mathrm{m}$, i.e., much larger than those of native casein micelles $(50-700 \mathrm{~nm})$, indicating that rCMs may merge into large particles due to the high phosphate content $(4.9 \mathrm{mM})$. Other authors [26], who prepared vitamin-D-loaded rCMs with the same approach, achieving a loading of $1.6 \mathrm{mg}$ vitamin $\mathrm{D}_{3} / 100 \mathrm{mg}$ casein, adopted a homogenization step of the mixture, and obtained a bimodal volume-weighted particle size distribution, with a large population that had an average volume moment-weighted diameter of $89 \mathrm{~nm}$, and a smaller population around $277 \mathrm{~nm}$ in diameter. The efficacy of casein complexes and rCMs in protecting the associated vitamin $\mathrm{D}_{2}$ from degradation was compared in fluid milk processed at the laboratory scale [51]. Disruption and subsequent reassembly of casein micelles with increased affinity for vitamin D was also attained using high-pressure (> $400 \mathrm{MPa})$ treatments at selected temperatures [62]. Large rCMs (278 $\mathrm{nm}$ average hydrodynamic diameter) with a vitamin $\mathrm{D}_{2}$ loading of $10.4 \mu \mathrm{g} / \mathrm{mg}$ casein were obtained by treating a dispersion of native micelles at $600 \mathrm{MPa}$ at $50{ }^{\circ} \mathrm{C}$. These structures were claimed to be suitable for the enrichment of low-fat dairy products, since they maintain the original properties [62].

Table 2. Formulation of vitamin D for food fortification.

\begin{tabular}{|c|c|c|c|c|}
\hline $\begin{array}{c}\text { Structures } \\
\text { and Vitamin D Loading }\end{array}$ & Components & PSD and Average Size & $\zeta$-Potential & Ref. \\
\hline $\begin{array}{c}\text { O/W emulsions } \\
\text { S, small; } \\
\text { M, medium; } \\
\text { L, large } \\
50 \text { mg vitamin } \mathrm{D}_{2} / 100 \mathrm{~g} \text { oil }\end{array}$ & $\begin{array}{l}\text { Vitamin } \mathrm{D}_{2} \text {, corn oil, Tween }{ }^{\circledR} 80, \\
\text { phosphate buffer }\end{array}$ & $\begin{array}{c}\text { Monomodal } \\
\text { S: } 0.11 \mu \mathrm{m}, \\
\text { M: } 0.53 \mu \mathrm{m}, \\
\text { L: } 14.5 \mu \mathrm{m} \text { (volume } \\
\text { moment-weighted mean diameter) }\end{array}$ & $\begin{array}{c}\mathrm{S}:-12.4 \mathrm{mV}, \mathrm{M}: \\
-14.1 \mathrm{mV} \\
\mathrm{L}:-13.8 \mathrm{mV}\end{array}$ & [36] \\
\hline $\begin{array}{l}\mathrm{O} / \mathrm{W} \text { nanoemulsion } \\
4 \mathrm{~g} \text { vitamin } \mathrm{D}_{3} / 100 \mathrm{~g} \text { oil }\end{array}$ & $\begin{array}{l}\text { Vitamin } \mathrm{D}_{3} \text {, corn oil, quillaja } \\
\text { saponin, phosphate buffer }\end{array}$ & $\begin{array}{c}\text { Monomodal } \\
0.14 \mu \mathrm{m} \text { (mean particle diameter) }\end{array}$ & $-36.4 \mathrm{mV}$ & [47] \\
\hline $\begin{array}{l}\mathrm{W}_{1} / \mathrm{O} / \mathrm{W}_{2} \text { double emulsion } \\
7 \mathrm{mg} \text { vitamin } \mathrm{D}_{3} / 100 \mathrm{~g} \text { oil }\end{array}$ & $\begin{array}{l}\text { Vitamin } \mathrm{D}_{3} \text {, vitamin } \mathrm{A} \text {, vitamin } \\
\mathrm{B}_{12} \text {, vitamin } \mathrm{C} \text {, chokeberry extract, } \\
\text { folic acid, rapeseed oil, } \\
\text { polyglycerol polyricinoleate, milk } \\
\text { protein, sodium chloride, water }\end{array}$ & 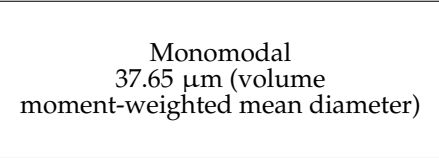 & & [48] \\
\hline $\begin{array}{l}\text { Liposomes } \\
20 \mathrm{~g} \text { vitamin } D_{3} / 100 \mathrm{~g} \text { lipid phase }\end{array}$ & $\begin{array}{l}\text { Vitamin } \mathrm{D}_{3}, \text { phospholipids, } \\
\text { cholesterol in ethanol, } \\
\text { distilled water }\end{array}$ & $\begin{array}{c}\text { Monomodal } \\
354.91 \mathrm{~nm} \text { (equivalent volume } \\
\text { diameter at } 50 \% \text { cumulative volume) }\end{array}$ & $-27.62 \mathrm{mV}$ & {$[50]$} \\
\hline $\begin{array}{c}\text { rCMs: reassembled casein micelles } \\
1.38-1.46 \mathrm{mg} \text { vitamin } \\
\mathrm{D}_{3} / 100 \mathrm{mg} \text { casein }\end{array}$ & $\begin{array}{l}\text { Vitamin } \mathrm{D}_{3} \text { in ethanol, sodium } \\
\text { caseinate in water, dipotassium } \\
\text { hydrogen phosphate, potassium } \\
\text { citrate, calcium chloride }\end{array}$ & $\begin{array}{l}\text { Monomodal } \\
\text { from } 16.10 \text { to } 19.04 \mu \mathrm{m} \text { (average } \\
\text { volume-weighted particle sizes) }\end{array}$ & $\begin{array}{l}\text { from }-17.3 \text { to } \\
\quad-17.8 \mathrm{mV}\end{array}$ & [61] \\
\hline $\begin{array}{l}\text { rCMs: reassembled casein micelles } \\
1.6 \mathrm{mg} \text { vitamin } \mathrm{D}_{3} / 100 \mathrm{mg} \text { casein }\end{array}$ & $\begin{array}{l}\text { Vitamin } \mathrm{D}_{3} \text { in ethanol, sodium } \\
\text { caseinate in water, dipotassium } \\
\text { hydrogen phosphate, tripotassium } \\
\text { citrate, calcium chloride }\end{array}$ & $\begin{array}{c}\text { Bimodal } \\
89 \mathrm{~nm} \text { and } 277 \mathrm{~nm} \text { (volume } \\
\text { moment-weighted mean diameter) }\end{array}$ & & [26] \\
\hline $\begin{array}{l}\text { rCMs: reassembled casein micelles } \\
1 \mu \mathrm{g} \text { vitamin } \mathrm{D}_{2} / 100 \mathrm{mg} \text { casein }\end{array}$ & $\begin{array}{l}\text { Vitamin } \mathrm{D}_{2} \text { in ethanol, micellar } \\
\text { casein in sweet whey permeate }\end{array}$ & $\begin{array}{l}\text { Monomodal } \\
\text { from } 145 \text { to } 303 \text { nm (mean } \\
\text { hydrodynamic diameter) }\end{array}$ & & [62] \\
\hline $\begin{array}{c}\beta \text {-Conglycinin nanoparticles } \\
10 \mu \mathrm{g} \text { vitamin } \mathrm{D}_{3} / 100 \mathrm{mg} \\
\beta \text {-conglycinin }\end{array}$ & $\begin{array}{c}\text { Vitamin } \mathrm{D}_{3} \text { in ethanol, } \\
\beta \text {-conglycinin, phosphate buffer }\end{array}$ & $\begin{array}{l}\text { Bimodal } \\
31 \mathrm{~nm} \text { and } 120 \mathrm{~nm} \text { (volume } \\
\text { weighted average particle diameter) }\end{array}$ & & [63] \\
\hline $\begin{array}{c}\text { Zein nanocapsules } \\
\text { vitamin } \mathrm{D}_{3} \text { loading not specified }\end{array}$ & $\begin{array}{c}\text { Vitamin } \mathrm{D}_{3} \text { in ethanol, zein, } \\
\text { Tween }{ }^{\circledR} 80\end{array}$ & $\begin{array}{c}\text { Monomodal } \\
185.7 \pm 2.10 \mathrm{~nm} \text { (Z-average size) }\end{array}$ & $24.5 \mathrm{mV}$ & [52] \\
\hline
\end{tabular}


Due to their wider consumer acceptance and lower costs compared to animal proteins, plant proteins were also studied as vehicles for numerous bioactive compounds. Vitamin $D_{3}$ was encapsulated in soybean $\beta$-conglycinin nanoparticles, leading to a bimodal distribution: a large population ( $90 \%$ of the particle volume) with an average volume moment-weighted diameter of $31 \mathrm{~nm}$, and the remaining $10 \%$ with a diameter around $120 \mathrm{~nm}$ [63]. These nanoparticles were claimed to be suitable for the fortification of both foods and clear beverages [63]. Zein — a major protein from corn-was successfully used to produce nanoparticles that were loaded with vitamin $\mathrm{D}_{3}$, attaining a $97.27 \%$ encapsulation efficiency [52]. In this case, nanoparticles had a Z-average size of $185.7 \mathrm{~nm}$ and, upon observation via transmission electron microscopy (TEM), showed a smooth surface. The $\zeta$-potential of $24.5 \mathrm{mV}$ was attributed to the cationic character of zein, because the value was similar $(21.2 \mathrm{mV})$ in the unloaded zein nanoparticles. A jelly based on the pulp of Acca sellowiana, xylitol, and pectin was then fortified with the nanoparticles [52].

The formulations described in Table 2 were generally tested in model foods: the $\mathrm{O} / \mathrm{W}$ emulsions were added to cheese [43] and almond milk [47], the $\mathrm{W}_{1} / \mathrm{O} / \mathrm{W}_{2}$ double emulsions were added to yogurt [49], liposomes were added to cheese [56] and chocolate [50], the rCMs were added to milk [51], and the zein nanocapsules were assessed in a model jelly food [52]. Although these model foods were prepared at the laboratory scale, they proved that the designed formulations could persist after processing and, thus, pave the way for applications in real food systems.

\section{Vitamin D in Fortified Foods: Yield and Stability}

The cis-triene configuration of vitamin D makes it potentially sensitive to isomerization and oxidation. Nevertheless, purified vitamin $\mathrm{D}_{3}$ was found to be stable at neutral $\mathrm{pH}$, in air, at ambient temperature [64]. Accordingly, a differential calorimetric study performed on the purified vitamins $D_{2}$ and $D_{3}$ revealed that the onset temperatures for their thermal decomposition are about 166 and $156^{\circ} \mathrm{C}$, respectively, and their activation energy values are 141 and $131 \mathrm{~kJ} \mathrm{~mol}^{-1}$, respectively [65]. However, vitamin D's stability can be affected by the food matrix components (Table 3 ).

In the presence of acids, vitamin $\mathrm{D}_{3}$ isomerizes, and its acid-catalyzed isomerization product-i.e., isotachysterol—is very oxygen-sensitive $[63,66]$. Moreover, vitamin $\mathrm{D}_{3}$ degradation is triggered by unsaturated lipid oxidation $[29,67]$. The reaction pattern for isomerization and oxidation of vitamin $\mathrm{D}_{3}$ does not involve the side chain that differs between vitamin $D_{2}$ and $D_{3}$; hence, these reactions most likely occur in vitamin $D_{2}$ as well.

Considering that vitamin $\mathrm{D}$ is often formulated as an oil phase before being used in food processing, some studies have investigated vitamin D's stability in bulk oils. Soybean oil packed in polyethylene terephthalate bottles was used as a model matrix to study the effects of oxidative status, antioxidant content ( $\alpha$-tocopherol), and exposure to light and oxygen on vitamin $\mathrm{D}_{3}$ degradation at $30^{\circ} \mathrm{C}$. This approach confirmed that the degradation of vitamin $\mathrm{D}_{3}$ occurs via oxidation, and the factors affecting degradation were, in decreasing order: storage time, exposure to light, and initial oxidative status of the oil, whereas $\alpha$ tocopherol content played a protective role. As a result, vitamin $\mathrm{D}_{3}$ retention after storage at $30^{\circ} \mathrm{C}$ for $50 \mathrm{~d}$ varied in the range $32-76 \%$ [29]. Sunflower oil was also used as a medium to study both vitamin $\mathrm{D}_{3}$ and vitamin $\mathrm{D}_{2}$ degradation at 100 and $210{ }^{\circ} \mathrm{C}$, and both isomers were found to degrade at a similar rate upon heating [31].

Formulation of vitamin $\mathrm{D}_{3}$ in lipids with a low degree of unsaturation led to higher stability. In fact, both free vitamin $\mathrm{D}_{3}$ and liposomes made with vitamin $\mathrm{D}_{3}$, phospholipids, and cholesterol added to white chocolate after conching resulted in total recovery of the vitamin in chocolate upon $120 \mathrm{~d}$ of storage at $25^{\circ} \mathrm{C}$ [50]. In contrast, a short-term stability of liposomes was observed in cheese upon ripening, leading to a progressive degradation of the loaded vitamin D [57].

Whole wheat flour was also considered for vitamin $\mathrm{D}_{3}$ incorporation, which is a strategy to develop various fortified bakery products [68]. In dry and intermediate-moisture foods, chemical stability is critically dependent on water activity $\left(a_{w}\right)$. For oxygen-sensitive 
compounds, stability decreases with increasing $\mathrm{a}_{\mathrm{w}}$ above the monomolecular moisture content, due to a decrease in the viscosity of the food matrix and increase in the molecular mobility, accelerating oxidation [69]. Accordingly, the half-times for vitamin $\mathrm{D}_{3}$ added to whole wheat flour at $25{ }^{\circ} \mathrm{C}$ were found to be 173,169 , and $116 \mathrm{~d}$ at $\mathrm{a}_{\mathrm{w}}$ levels of 0.33 , 0.63 , and 0.93 , respectively. The stability of vitamin $\mathrm{D}_{3}$ greatly decreases with increasing temperature to $45^{\circ} \mathrm{C}$, with half-times for degradation of 87,77 , and $63 \mathrm{~d}$ at $\mathrm{a}_{\mathrm{w}}$ of $0.33,0.63$, and 0.93 , respectively [68].

Dry irradiated mushroom powder could represent a source of vitamin $\mathrm{D}_{2}$ for a variety of foods [70]; in this matrix, vitamin $\mathrm{D}_{2}$ stability was also found to decrease with increasing $\mathrm{a}_{\mathrm{w}}$ from 0.11 to 0.75 [71]. The activation energy found for vitamin $\mathrm{D}_{2}$ degradation in mushroom powder at $a_{w} 0.33$ was $36.7 \mathrm{~kJ} / \mathrm{mol}$, which is close to the activation energy for oxygen diffusion in unsaturated lipids-i.e., $24 \mathrm{~kJ} / \mathrm{mol}$ - and to the activation energies found for the free radical chain reactions in triglycerides-i.e., $34.0-37.3 \mathrm{~kJ} / \mathrm{mol}$ [72]; hence, autoxidation was assumed to be the mechanism by which vitamin $\mathrm{D}_{2}$ was lost [71]. The half-life of vitamin $D_{2}$ at $a_{w} 0.33$, calculated on the basis of the activation energy provided by this latter study, was $175 \mathrm{~d}$ at $25^{\circ} \mathrm{C}$, which is the same as that found for vitamin $\mathrm{D}_{3}$ in whole wheat flour under the same temperature and $\mathrm{a}_{\mathrm{w}}$ conditions [68]. Conversely, in fresh irradiated mushrooms, vitamin $\mathrm{D}_{2^{\prime}} \mathrm{s}$ half-life was approximately $7 \mathrm{~d}$ at both $4{ }^{\circ} \mathrm{C}$ and $-14{ }^{\circ} \mathrm{C}$ [73]; hence, storage at $-20{ }^{\circ} \mathrm{C}$ is necessary to preserve vitamin $\mathrm{D}_{2}$ in fresh mushroom [74].

Table 3. Recovery of vitamin D in fortified foods after processing and storage.

\begin{tabular}{|c|c|c|c|c|}
\hline Fortified Food & $\begin{array}{c}\text { Vitamin D } \\
\text { Content }(\mu \mathrm{g} / 100 \mathrm{~g})\end{array}$ & Main Processing Steps & $\underset{(\%)}{\operatorname{Vitamin} D}$ Yield & Ref. \\
\hline \multirow[b]{2}{*}{$\begin{array}{l}\text { Free vitamin } \mathrm{D}_{3} \\
\text { in soybean oil }\end{array}$} & \multirow[b]{2}{*}{700} & Storage in PET bottles at $30^{\circ} \mathrm{C}$ for $50 \mathrm{~d}$ in the dark & $56-76(S)$ & \multirow[b]{2}{*}{ [29] } \\
\hline & & $\begin{array}{c}\text { Storage in PET bottles at } 30^{\circ} \mathrm{C} \text { for } 50 \mathrm{~d} \text { under } \\
\text { natural light }\end{array}$ & $32-39(S)$ & \\
\hline \multirow{2}{*}{$\begin{array}{l}\text { Free vitamin } \mathrm{D}_{3} \\
\text { in sunflower oil }\end{array}$} & \multirow{2}{*}{14.5} & Heating at $110^{\circ} \mathrm{C}$ for $30 \mathrm{~min}$ & $85(\mathrm{P})$ & \multirow{4}{*}[31]{} \\
\hline & & Heating at $210^{\circ} \mathrm{C}$ for $10 \mathrm{~min}$ & $79(\mathrm{P})$ & \\
\hline \multirow{2}{*}{$\begin{array}{l}\text { Free vitamin } \mathrm{D}_{2} \\
\text { in sunflower oil }\end{array}$} & \multirow{2}{*}{11.2} & Heating at $110^{\circ} \mathrm{C}$ for $30 \mathrm{~min}$ & $89(\mathrm{P})$ & \\
\hline & & Heating at $210^{\circ} \mathrm{C}$ for $10 \mathrm{~min}$ & $76(\mathrm{P})$ & \\
\hline $\begin{array}{l}\text { Vitamin } \mathrm{D}_{3} \text { in liposomes } \\
\text { in white chocolate }\end{array}$ & \multirow{2}{*}{30} & \multirow{2}{*}{$\begin{array}{l}\text { Three-step tempering process }\left(33^{\circ} \mathrm{C}-35^{\circ} \mathrm{C} \text {, }\right. \\
\left.24^{\circ} \mathrm{C}-25^{\circ} \mathrm{C} \text {, and } 25^{\circ} \mathrm{C}-26^{\circ} \mathrm{C}\right), \\
\text { storage at } 25^{\circ} \mathrm{C} \text { for } 120 \mathrm{~d}\end{array}$} & $100(S)$ & \multirow{2}{*}[50]{} \\
\hline $\begin{array}{l}\text { Free vitamin } \mathrm{D}_{3} \\
\text { in white chocolate }\end{array}$ & & & $99(\mathrm{~S})$ & \\
\hline \multirow{4}{*}{$\begin{array}{l}\text { Free vitamin } \mathrm{D}_{3} \\
\text { in whole wheat flour }\end{array}$} & \multirow{4}{*}{ nd } & Storage at $\mathrm{a}_{\mathrm{w}} 0.33$ at $25^{\circ} \mathrm{C}$ for $173 \mathrm{~d}$ & $50(S)$ & \multirow{4}{*}[68]{} \\
\hline & & Storage at $\mathrm{a}_{\mathrm{w}} 0.93$ at $25^{\circ} \mathrm{C}$ for $116 \mathrm{~d}$ & $50(S)$ & \\
\hline & & Storage at $\mathrm{a}_{\mathrm{w}} 0.33$ at $45^{\circ} \mathrm{C}$ for $87 \mathrm{~d}$ & $50(S)$ & \\
\hline & & Storage at $\mathrm{a}_{\mathrm{w}} 0.93$ at $45^{\circ} \mathrm{C}$ for $63 \mathrm{~d}$ & $50(S)$ & \\
\hline \multirow{3}{*}{$\begin{array}{l}\text { Vitamin } \mathrm{D}_{2} \\
\text { in dry mushroom powder }\end{array}$} & \multirow{3}{*}{4420} & Storage at $\mathrm{a}_{\mathrm{w}} 0.33$ at $25^{\circ} \mathrm{C}$ for $175 \mathrm{~d}$ & $50(S)$ & \multirow{3}{*}[71]{} \\
\hline & & Storage at $\mathrm{a}_{\mathrm{w}} 0.33$ at $30^{\circ} \mathrm{C}$ for $136 \mathrm{~d}$ & $50(S)$ & \\
\hline & & Storage at $\mathrm{a}_{\mathrm{w}} 0.33$ at $45^{\circ} \mathrm{C}$ for $55 \mathrm{~d}$ & $50(S)$ & \\
\hline $\begin{array}{l}\text { Free vitamin } D_{3} \\
\text { in wheat bread }\end{array}$ & 10.8 & \multirow{4}{*}{ Baking at $170{ }^{\circ} \mathrm{C}$ for $60 \mathrm{~min}$} & $85(\mathrm{P})$ & \multirow{4}{*}{ [28] } \\
\hline $\begin{array}{l}\text { Free vitamin } D_{3} \\
\text { in rye bread }\end{array}$ & 8.7 & & $69(\mathrm{P})$ & \\
\hline $\begin{array}{l}\text { Vitamin } \mathrm{D}_{2} \text { yeast } \\
\text { in wheat bread }\end{array}$ & 9.5 & & $85(\mathrm{P})$ & \\
\hline $\begin{array}{l}\text { Vitamin } D_{2} \text { yeast } \\
\text { in rye bread }\end{array}$ & 8.5 & & $73(\mathrm{P})$ & \\
\hline $\begin{array}{l}\text { Free vitamin } D_{3} \\
\text { in wheat bread }\end{array}$ & 40.2 & Baking at $200^{\circ} \mathrm{C}$ for $20 \mathrm{~min}$ & $40.2(\mathrm{P})$ & \multirow{2}{*}{ [68] } \\
\hline $\begin{array}{l}\text { Free vitamin } \mathrm{D}_{3} \\
\text { in cookies }\end{array}$ & 64 & Baking at $200-205^{\circ} \mathrm{C}$ for $12 \mathrm{~min}$ & $65.3(\mathrm{P})$ & \\
\hline
\end{tabular}


Table 3. Cont.

\begin{tabular}{|c|c|c|c|c|}
\hline Fortified Food & $\begin{array}{c}\text { Vitamin D } \\
\text { Content }(\mu \mathrm{g} / 100 \mathrm{~g})\end{array}$ & Main Processing Steps & $\underset{(\%)}{\operatorname{Vitamin} D}$ Yield & Ref. \\
\hline $\begin{array}{l}\text { Free vitamin } D_{3} \\
\text { in milk }\end{array}$ & 12 & $\begin{array}{l}\text { Steam injection }\left(95^{\circ} \mathrm{C}\right) \text {, spray-drying at } 149^{\circ} \mathrm{C} \text {, } \\
\text { fluid-bed finish at } 107^{\circ} \mathrm{C}\end{array}$ & $100(\mathrm{P})$ & [27] \\
\hline $\begin{array}{l}\text { Water-dispersible vitamin } \mathrm{D}_{3} \\
\text { in milk }\end{array}$ & 100 & $\begin{array}{c}\text { Pasteurization at } 73{ }^{\circ} \mathrm{C} \text { for } 15 \mathrm{~s}, \text { homogenization at } \\
13.8 / 3.4 \mathrm{MPa} \text {, storage at } 4^{\circ} \mathrm{C} \text { for } 21 \mathrm{~d}\end{array}$ & $100(\mathrm{P}, \mathrm{S})$ & [37] \\
\hline \multirow{5}{*}{$\begin{array}{l}\text { Water-dispersible vitamin } \mathrm{D}_{2} \\
\text { in milk }\end{array}$} & \multirow{5}{*}{2} & $\begin{array}{l}\text { Pasteurization at } 63^{\circ} \mathrm{C} \text { for } 30 \mathrm{~min} \text {, storage in glass } \\
\text { bottles at } 4^{\circ} \mathrm{C} \text { for } 7 \mathrm{~d} \text { in the dark }\end{array}$ & $100(\mathrm{P}, \mathrm{S})$ & \multirow{5}{*}{ [39] } \\
\hline & & $\begin{array}{c}\text { Pasteurization at } 63^{\circ} \mathrm{C} \text { for } 30 \mathrm{~min} \text {, storage in glass } \\
\text { bottles at } 4{ }^{\circ} \mathrm{C} \text { for } 32 \mathrm{~h} \text { under light }\end{array}$ & $100(\mathrm{P}, \mathrm{S})$ & \\
\hline & & $\begin{array}{l}\text { Pasteurization at } 63^{\circ} \mathrm{C} \text { for } 30 \mathrm{~min} \text {, storage in PET } \\
\text { pouches at } 4^{\circ} \mathrm{C} \text { for } 7 \mathrm{~d} \text { in the dark }\end{array}$ & $\sim 90(\mathrm{P}, \mathrm{S})$ & \\
\hline & & $\begin{array}{c}\text { Pasteurization at } 63^{\circ} \mathrm{C} \text { for } 30 \mathrm{~min} \text {, storage in PET } \\
\text { pouches at } 4{ }^{\circ} \mathrm{C} \text { for } 32 \mathrm{~h} \text { under light }\end{array}$ & $\sim 90(\mathrm{P}, \mathrm{S})$ & \\
\hline & & Sterilization at $121^{\circ} \mathrm{C}$ for $15 \mathrm{~min}$ & $100(\mathrm{P})$ & \\
\hline \multirow{3}{*}{$\begin{array}{l}\text { Vitamin } \mathrm{D}_{2} \text { in casein } \\
\text { complexes } \\
\text { in cow and buffalo milk }(1: 1)\end{array}$} & \multirow{3}{*}{1.25} & $\begin{array}{l}\text { Pasteurization at } 63^{\circ} \mathrm{C} \text { for } 30 \mathrm{~min} \text {, storage in glass } \\
\text { bottles at } 4{ }^{\circ} \mathrm{C} \text { for } 7 \mathrm{~d} \text { under light }\end{array}$ & $\begin{array}{l}\sim 95(\mathrm{P}) \\
\sim 70(\mathrm{~S})\end{array}$ & \multirow{6}{*}[51]{} \\
\hline & & $\begin{array}{c}\text { Pasteurization at } 63^{\circ} \mathrm{C} \text { for } 30 \mathrm{~min} \text {, storage in LDPE } \\
\text { pouches at } 4{ }^{\circ} \mathrm{C} \text { for } 7 \mathrm{~d} \text { under light }\end{array}$ & $\begin{array}{l}\sim 95(\mathrm{P}) \\
\sim 65(\mathrm{~S})\end{array}$ & \\
\hline & & Sterilization at $121^{\circ} \mathrm{C}$ for $15 \mathrm{~min}$ & $\sim 75(\mathrm{P})$ & \\
\hline \multirow{3}{*}{$\begin{array}{c}\text { Free vitamin } \mathrm{D}_{2} \\
\text { in cow and buffalo milk (1:1) }\end{array}$} & \multirow{3}{*}{1.25} & $\begin{array}{c}\text { Pasteurization at } 63^{\circ} \mathrm{C} \text { for } 30 \mathrm{~min} \text {, storage in glass } \\
\text { bottles at } 4{ }^{\circ} \mathrm{C} \text { for } 7 \mathrm{~d} \text { under light }\end{array}$ & $\begin{array}{l}90(\mathrm{P}) \\
45(\mathrm{~S})\end{array}$ & \\
\hline & & $\begin{array}{l}\text { Pasteurization at } 63^{\circ} \mathrm{C} \text { for } 30 \mathrm{~min} \text {, storage in LDPE } \\
\text { pouches at } 4^{\circ} \mathrm{C} \text { for } 7 \mathrm{~d} \text { under light }\end{array}$ & $\begin{array}{l}90(\mathrm{P}), \\
45(\mathrm{~S})\end{array}$ & \\
\hline & & Sterilization at $121^{\circ} \mathrm{C}$ for $15 \mathrm{~min}$ & $67(\mathrm{P})$ & \\
\hline $\begin{array}{l}\text { Water-dispersible vitamin } \mathrm{D}_{3} \\
\text { in Cheddar (milk fat } 3.9 \% \text { ) }\end{array}$ & \multirow{2}{*}{ nd } & \multirow{2}{*}{$\begin{array}{l}\text { Starter addition, rennet addition, salting, pressing, } \\
\text { vacuum packaging, storage at } 4^{\circ} \mathrm{C} \text { for } 84 \mathrm{~d}\end{array}$} & $\begin{array}{l}90.4(\mathrm{P}) \\
100(\mathrm{~S})\end{array}$ & \multirow{2}{*}{ [34] } \\
\hline $\begin{array}{c}\text { Free vitamin } \mathrm{D}_{3} \\
\text { in Cheddar (milk fat } 3.9 \% \text { ) }\end{array}$ & & & $\begin{array}{c}86.7(\mathrm{P}) \\
93.7 \%(\mathrm{~S})\end{array}$ & \\
\hline $\begin{array}{l}\text { Water-dispersible vitamin } \mathrm{D}_{3} \\
\text { in Cheddar (milk fat } 3.8 \% \text { ) }\end{array}$ & 2085 & \multirow{2}{*}{$\begin{array}{l}\text { Milk pasteurization } 72^{\circ} \mathrm{C} \text { for } 16 \mathrm{~s} \text {, starter addition, } \\
\text { rennet addition, salting, pressing, vacuum } \\
\text { packaging, storage at } 4{ }^{\circ} \mathrm{C} \text { for } 365 \mathrm{~d}\end{array}$} & $\begin{array}{c}91(\mathrm{P}) \\
100(\mathrm{~S})\end{array}$ & \multirow[b]{2}{*}{ [35] } \\
\hline $\begin{array}{c}\text { Water-dispersible vitamin } \mathrm{D}_{3} \\
\text { in low-fat cheese (milk fat } \\
0.8 \% \text { ) }\end{array}$ & 1690 & & $\begin{array}{c}55(\mathrm{P}) \\
100(\mathrm{~S})\end{array}$ & \\
\hline $\begin{array}{l}\text { Vitamin } \mathrm{D}_{3} \text { in nanoemulsion } \\
\text { in cheese (milk fat } 2 \% \text { ) }\end{array}$ & 1 & $\begin{array}{l}\text { Milk acidification with lactic acid, rennet addition, } \\
\text { cutting, centrifugation, storage at } 4^{\circ} \mathrm{C} \text { for } 90 \mathrm{~d}\end{array}$ & $\begin{array}{r}91(\mathrm{P}) \\
100(\mathrm{~S})\end{array}$ & [43] \\
\hline $\begin{array}{c}\text { Free vitamin } \mathrm{D}_{3} \\
\text { in cheese }(17 \mathrm{MPa}, 0.9 \mathrm{P} / \mathrm{F} \\
\text { ratio) }\end{array}$ & 488 & \multirow{2}{*}{$\begin{array}{l}\text { Skimmed milk powder added with anhydrous milk } \\
\text { fat and water at specific protein/fat }(\mathrm{P} / \mathrm{F}) \text { ratio, } \\
\text { homogenization at } 17-150 \mathrm{MPa} \text {, calcium chloride } \\
\text { addition, coagulation at } 85^{\circ} \mathrm{C} \text {, salting, pressing }\end{array}$} & $52(\mathrm{P})$ & \multirow{2}{*}[32]{} \\
\hline $\begin{array}{c}\text { Free vitamin } \mathrm{D}_{3} \\
\text { in cheese }(150 \mathrm{MPa}, 2 \mathrm{P} / \mathrm{F} \\
\text { ratio) }\end{array}$ & 499 & & $49.3(\mathrm{P})$ & \\
\hline $\begin{array}{l}\text { Water-dispersible vitamin } \mathrm{D}_{3} \\
\text { in yogurt (milk fat } 3.9 \%)\end{array}$ & \multirow{2}{*}{ nd } & \multirow{2}{*}{$\begin{array}{l}\text { Starter inoculation, fermentation, storage at } 4{ }^{\circ} \mathrm{C} \text { for } \\
\qquad 21 \mathrm{~d}\end{array}$} & $\begin{array}{l}97.8(\mathrm{P}) \\
100(\mathrm{~S})\end{array}$ & \multirow{2}{*}{ [34] } \\
\hline $\begin{array}{c}\text { Free vitamin } \mathrm{D}_{3} \\
\text { in yogurt (milk fat } 3.9 \%)\end{array}$ & & & $\begin{array}{l}96.6(\mathrm{P}) \\
100(\mathrm{~S})\end{array}$ & \\
\hline $\begin{array}{l}\text { Vitamin } \mathrm{D}_{3} \text { in } \mathrm{W} / \mathrm{O} \text { emulsion } \\
\text { in yogurt }\end{array}$ & \multirow{2}{*}{12.5} & \multirow{2}{*}{ Addition to fresh yogurt, storage at $4{ }^{\circ} \mathrm{C}$ for $20 \mathrm{~d}$} & $15.97(\mathrm{~S})$ & \multirow{2}{*}{ [45] } \\
\hline $\begin{array}{l}\text { Vitamin } \mathrm{D}_{3} \text { in } \mathrm{W} / \mathrm{O} \text { emulsion } \\
\text { in yogurt + goji berry extract }\end{array}$ & & & $74.90(\mathrm{~S})$ & \\
\hline $\begin{array}{l}\text { Water-dispersible vitamin } \mathrm{D}_{3} \\
\text { in yogurt (milk fat } 1.5 \% \text { ) }\end{array}$ & \multirow{2}{*}{2.25} & \multirow{2}{*}{$\begin{array}{l}\text { Starter inoculation, fermentation, storage in opaque } \\
\text { containers at } 4{ }^{\circ} \mathrm{C} \text { for } 21 \mathrm{~d}\end{array}$} & $100(S)$ & \multirow{4}{*}[38]{} \\
\hline $\begin{array}{l}\text { Vitamin } \mathrm{D}_{3} \text { in oil } \\
\text { in yogurt (milk fat } 1.5 \%)\end{array}$ & & & $99(\mathrm{~S})$ & \\
\hline $\begin{array}{l}\text { Water-dispersible vitamin } \mathrm{D}_{3} \\
\text { in yogurt (milk fat } 1.5 \%)\end{array}$ & \multirow{2}{*}{2.25} & \multirow{2}{*}{$\begin{array}{l}\text { Starter inoculation, fermentation, storage in } \\
\text { transparent containers at } 4{ }^{\circ} \mathrm{C} \text { for } 21 \mathrm{~d}\end{array}$} & $86(S)$ & \\
\hline $\begin{array}{c}\text { Vitamin } \mathrm{D}_{3} \text { in oil } \\
\text { in yogurt (milk fat } 1.5 \%)\end{array}$ & & & $80(S)$ & \\
\hline $\begin{array}{l}\text { Vitamin } \mathrm{D}_{3} \text { in } \mathrm{W}_{1} / \mathrm{O} / \mathrm{W}_{2} \\
\text { emulsion } \\
\text { in yogurt (milk fat } 6.15 \%)\end{array}$ & \multirow{2}{*}{10} & \multirow{2}{*}{$\begin{array}{l}\text { Starter inoculation, fermentation, storage at } 4{ }^{\circ} \mathrm{C} \text { for } \\
\qquad 20 \mathrm{~d}\end{array}$} & $50(S)$ & \multirow{2}{*}{ [49] } \\
\hline $\begin{array}{c}\text { Free vitamin } \mathrm{D}_{3} \\
\text { in yogurt (milk fat } 6.15 \%)\end{array}$ & & & $94(S)$ & \\
\hline
\end{tabular}

$(\mathrm{P}, \mathrm{S})$ : recovery after processing and storage; (P): recovery after processing; (S): recovery after storage; nd: not reported. 
A bread model provided evidence of the effects of acid compounds on vitamin $\mathrm{D}_{2}$ degradation. In fact, in rye and wheat bread fortified with vitamin $\mathrm{D}_{2}$ from dry yeast, the retention after baking at $170{ }^{\circ} \mathrm{C}$ for $60 \mathrm{~min}$ was $73 \%$ and $85 \%$, respectively. The same retention percentages were observed when free vitamin $\mathrm{D}_{3}$ was applied to fortify rye and wheat bread. Rye bread has a lower $\mathrm{pH}$ than wheat bread, which was the explanation for the lower retention of vitamin $\mathrm{D}$, due to the acid-catalyzed isomerization to isotachysterol [28]. In another fortification study of bread fortified with free vitamin $\mathrm{D}_{3}$, retention was only $40 \%$, but baking was carried out at a higher temperature, i.e., $200{ }^{\circ} \mathrm{C}$ for $20 \mathrm{~min}$ [68]. For cookies baked at $200-205^{\circ} \mathrm{C}$ for a shorter time $(12 \mathrm{~min})$, the retention of vitamin $\mathrm{D}_{3}$ was $65 \%$ [68].

Milk intended for direct use or further processing in dairy products was also considered as a matrix to incorporate either vitamin $D_{3}$ or vitamin $D_{2}$. Nevertheless, contradictory results have been reported in literature regarding vitamin D's stability in milk upon processing and storage. Natural vitamin $\mathrm{D}_{3}$ present in milk was reported to be unstable upon pasteurization and sterilization [57]. Conversely, free vitamin $\mathrm{D}_{3}$ added directly to milk before steam injection at $95^{\circ} \mathrm{C}$, spray-drying at $149^{\circ} \mathrm{C}$, and fluid-bed finishing at $107^{\circ} \mathrm{C}$ was completely recovered in the dried milk powder [27]. In another study, the percentages of recovery for free vitamin $\mathrm{D}_{2}$ in milk after pasteurization at $63{ }^{\circ} \mathrm{C}$ for $30 \mathrm{~min}$ and sterilization at $121^{\circ} \mathrm{C}$ for $15 \mathrm{~min}$ were 90 and $67 \%$, respectively [51]. In some applications, both vitamin $\mathrm{D}_{3}$ and vitamin $\mathrm{D}_{2}$ were previously formulated in water-dispersible forms before addition to milk $[37,39]$. Pasteurization at $73^{\circ} \mathrm{C}$ for $15 \mathrm{~s}$, homogenization at $13.8 / 3.4 \mathrm{MPa}$, and storage in opaque plastic containers (with no further specifications) at $4{ }^{\circ} \mathrm{C}$ for $21 \mathrm{~d}$ did not affect the content of water-dispersible vitamin $\mathrm{D}_{3}$ added to milk [37]. Complete retention of vitamin $\mathrm{D}_{3}$ was also observed upon UHT processing $\left(138^{\circ} \mathrm{C}\right.$ for $\left.2 \mathrm{~s}\right)$ of chocolate milk with $2 \%$ added fat [37]. Similarly, water-dispersible vitamin $\mathrm{D}_{2}$ was found to be stable in milk upon pasteurization at $63^{\circ} \mathrm{C}$ for $30 \mathrm{~min}$ and storage at $4{ }^{\circ} \mathrm{C}$ for $7 \mathrm{~d}$ in glass bottles in the dark, or for $32 \mathrm{~h}$ under light (1485-4455 lux), while vitamin $\mathrm{D}_{2}$ retention was $\sim 90 \%$ when polyethylene pouches were used as a packaging material, regardless of light exposure during storage. This phenomenon was attributed to absorption of vitamin $\mathrm{D}_{2}$ by the polymer [39]. Sterilization at $121^{\circ} \mathrm{C}$ for $15 \mathrm{~min}$ also resulted in total recovery of water-dispersible vitamin $\mathrm{D}_{2}$, while the retention during the storage of sterilized milk was not investigated [39].

In another approach, vitamin $\mathrm{D}_{2}$ complexed with casein in rCMs was added to milk and found to have improved stability with respect to the free vitamin $\mathrm{D}_{2}$ after pasteurization and sterilization, with recovery percentages up to 95 and $76 \%$, respectively [51]. This latter study also reported the effect of storage on vitamin $\mathrm{D}_{2^{\prime}}, \mathrm{s}$ stability in milk packed in glass bottles or low-density polyethylene pouches, which was 70 and $65 \%$, respectively, for vitamin $D_{2}$ in casein complexes, and approximately $45 \%$ for free vitamin $D_{2}$ regardless of the packaging material used [51]. Loss of vitamin $\mathrm{D}_{2}$ in milk packed in polyethylene pouches was attributed to the porous and hydrophobic nature of this material, which promotes absorption of vitamin $\mathrm{D}_{2}[39,51]$. Moreover, during exposure of milk to light, singlet oxygen is produced, which causes degradation of vitamin D. It is worth noting that, in milk, riboflavin acts as a photosensitizer, thus accelerating the formation of singlet oxygen and leading to the photo-oxidation of vitamin $\mathrm{D}[75,76]$.

In cheese, the retention of vitamin $\mathrm{D}$ is a key aspect to optimize. In fact, during cheese-making, the fat-soluble vitamin $\mathrm{D}_{3}$ could be entrapped in the fat fraction that mostly precipitates in the curd. However, vitamin $\mathrm{D}_{3}$ possesses high affinity towards both $\beta$-lactoglobulin [77] and $\alpha$-lactalbumin [78]; hence, it could also be lost in whey [34]. Cheddar cheese obtained from vitamin- $\mathrm{D}_{3}$-fortified full-fat milk $(3.9 \%$ fat, $w / w)$ showed approximately $90 \%$ recovery, regardless of the form in which vitamin $\mathrm{D}_{3}$ (free or waterdispersible) was added. The addition of vitamin $\mathrm{D}_{3}$ nanoemulsion to partially defatted milk $(2.0 \%$ fat, $w / w)$ also resulted in $91 \%$ recovery in cheese [43]. Conversely, when waterdispersible vitamin $\mathrm{D}_{3}$ was added to reduced-fat milk $(0.78 \%, w / w)$, and further processed to Cheddar cheese, the recovery yield was only $55 \%$ [35]. Low recovery of vitamin $D_{3}$, 
equal to $50 \%$, was also observed upon the application of a model cheese-making process, based on heat-induced coagulation at $82^{\circ} \mathrm{C}$ in the presence of calcium chloride, regardless of the pressure applied (17-150 MPa) or the protein-to-fat ratio (0.9-2) [32]. During storage, vitamin $\mathrm{D}_{3^{\prime}}$ s stability was high for up to 1 year in both full-fat and reduced-fat cheese [35].

Full-fat yogurt was fortified with both free and water-dispersible vitamin $\mathrm{D}_{3}$ and stored at $4{ }^{\circ} \mathrm{C}$ for $21 \mathrm{~d}$, achieving almost complete recovery with both approaches [34]. Lowfat yogurt was also fortified with both water-dispersible vitamin $\mathrm{D}_{3}$ and oil-dispersible vitamin $\mathrm{D}_{3}$, and vitamin recovery was found to be complete after $21 \mathrm{~d}$ of storage at $4{ }^{\circ} \mathrm{C}$ when opaque packaging material was used, while approximately $80 \%$ recovery was observed when transparent packaging material was used [38]. However, in another fortification study, a O/W nanoemulsion of vitamin $\mathrm{D}_{3}$ made with coconut oil, soybean lecithin, Tween 80 , and $\mathrm{NaCl}$ was added to yogurt before packaging (packaging material was not specified), and only $15.97 \%$ of vitamin $\mathrm{D}_{3}$ was recovered after storage at $4{ }^{\circ} \mathrm{C}$ for $20 \mathrm{~d}$, unless goji berry antioxidants were added, which allowed $74.90 \%$ of vitamin $\mathrm{D}_{3}$ to be recovered [45]. Similarly, in a subsequent study, the addition of free vitamin $\mathrm{D}_{3}$ to yogurt led to a recovery of $50 \%$ after storage (packaging material was not specified), while the addition of a $\mathrm{W}_{1} / \mathrm{O} / \mathrm{W}_{2}$ double emulsion made of refined rapeseed oil, polyglycerol polyricinoleate, milk protein concentrate, sodium chloride, and sucrose led to $94 \%$ recovery [49]. One possible mechanism for free vitamin $\mathrm{D}_{3}$ degradation in yogurt observed in this latter study could be oxidation, triggered by the high fat content $(6.5 \%)$, whereas the emulsion protected vitamin $\mathrm{D}_{3}$ from oxidation.

\section{Vitamin D in Fortified Foods: Bioaccessibility}

Vitamin D is dissolved within the hydrophobic domains of the food matrices-such as bulk oils, fat droplets, or liposomes-or it is associated with proteins $[79,80]$. The metabolism of vitamin D begins in the stomach, where pepsin plays a role by releasing the fraction of vitamin $\mathrm{D}$ associated with proteins, and the gastric lipase hydrolyses vitamin $\mathrm{D}$ esters at least partially.

The fundamental step of vitamin D metabolism occurs in the duodenum, where proteases and lipases carry on its release from the food matrix and allow its solubilization in the mixed micelles formed from lipid digestion products, such as free fatty acids, monoglycerides, bile salts, and phospholipids. Then, vitamin $\mathrm{D}$ absorption by the epithelial cells takes place, which is mainly protein-mediated at low dietary concentrations and passive at high, pharmacological concentrations of vitamin D [79].

Hence, as for the other fat-soluble vitamins, the bioavailability of vitamin D depends on three phenomena: bioaccessibility (release from the lipid phase of the food matrix and solubilization within mixed micelles); transformation (chemical and biochemical conversion); and transport and uptake (migration through the mucus layer to the surfaces of the intestinal lumen and absorption by epithelial cells) [80]. Among these phenomena, bioaccessibility is the most critical in terms of governing bioavailability [81].

The effect of the food matrix on vitamin D bioavailability is not fully understood. The presence of lipids could improve vitamin D bioavailability by several mechanisms: providing a hydrophobic phase where it can be solubilized; stimulating biliary secretion and, consequently, micelle production; and contributing to micelle formation with their lipid digestion products, inducing chylomicron synthesis, which enhances vitamin $\mathrm{D}$ transport outside the enterocytes [79]. Nevertheless, in vivo studies available to date neglect the hypothesis that high amounts of fat in meals improve vitamin D's bioavailability [44,79].

Dietary fiber seems to impair vitamin D's bioavailability by affecting micelle formation and by increasing the viscosity of the chime, thus limiting the diffusion of vitamin-Dcontaining micelles to the brush border [79]. However, in vivo studies do not provide enough data to conclude on the effects of dietary components on vitamin D's bioavailability.

As discussed previously, data on vitamin D's bioavailability from food matrices obtained in various studies are difficult to compare because of the different study plans, including subjects involved, amount of vitamin D administered, and duration of the 
intervention [79]. In particular, vitamin D's bioavailability is thought to depend on humanassociated factors (age, disease, surgery, obesity, genetic variation, etc.) [45]. In vitro studies can provide insights on the effect of the food matrix on vitamin D's release in the gastrointestinal tract and, hence, support the design of fortified foods (Table 4).

Bread was studied as a food matrix for vitamin D incorporation. Vitamin $\mathrm{D}_{2}$ from UV-treated yeast was used for both white and whole bread production, and the resulting bioaccessibility percentages were 15 and $9.9 \%$, respectively. However, the bioaccessibility of free vitamin $\mathrm{D}_{2}$ in bread was higher (38\%). It was concluded that the yeast cells entrapped vitamin $\mathrm{D}_{2}$ and hindered its incorporation into the mixed micelles [30]. As reported above, an in vivo study also led to the conclusion that bread made with UV-irradiated yeast as a source of vitamin $\mathrm{D}_{2}$ did not raise serum levels of $25(\mathrm{OH}) \mathrm{D}$, while supplements of both vitamin $D_{2}$ and vitamin $D_{3}$ resulted in a positive effect [18].

Various milk and dairy matrices were used for vitamin $\mathrm{D}_{3}$ incorporation. Skimmed milk, partially defatted milk ( $2 \%$ fat), whole milk ( $3.25 \%$ fat), and a standard infant formula powder ( $4 \%$ fat) were fortified with vitamin $\mathrm{D}_{3}$ and studied for vitamin $\mathrm{D}_{3}$ bioaccessibility [30]. Results showed that, with respect to the initial content, the recovery of vitamin $\mathrm{D}_{3}$ in the intestinal digesta was only $40 \%$ for skimmed milk, $88 \%$ for partially defatted milk, 75\% for whole milk, and 77\% for infant formula. In general, only a part of vitamin $\mathrm{D}_{3}$ found in the digesta was effectively incorporated in the mixed micelles, equal to $70 \%$ for whole milk and infant formula and $80 \%$ for partially defatted milk and skimmed milk. Hence, considering bioaccessibility as the percentage of vitamin $\mathrm{D}_{3}$ recovered in the micellar phase after in vitro digestion compared to the amount of vitamin $\mathrm{D}_{3}$ in food, it can be calculated that bioaccessibility was $32,70,53$, and $54 \%$ for skimmed milk, partially defatted milk, whole milk, and infant formula, respectively. It was concluded that bovine milk is an efficient delivery vehicle for vitamin $D_{3^{\prime}}$ s bioaccessibility, even if the optimal amount of lipid for in vivo bioavailability of vitamin $\mathrm{D}_{3}$ requires further investigation [30], as observed in vivo [79].

Digestion models have also been tailored to specific populations, because the functioning of the gastrointestinal tract is known to depend on factors such as age and health status [80]. Three in vitro elderly models-namely, oral altered conditions; oral and gastric altered conditions; and oral, gastric, and intestinal altered conditions-were applied in parallel with a healthy adult model to investigate the digestibility of dairy products [82]. Interestingly, vitamin $\mathrm{D}_{3}$ naturally present in milk, yogurt, fresh cheese, and aged cheese was equally bioavailable for both the healthy and unhealthy gastrointestinal tract models considered, suggesting that age does not alter vitamin $\mathrm{D}_{3^{\prime}} \mathrm{s}$ bioaccessibility. On the other hand, vitamin $\mathrm{D}_{3^{\prime}}$ s bioaccessibility from milk was found to be $30 \%$, which is lower than that reported previously [30]. Moreover, vitamin D's bioaccessibility was reported to be greatly dependent on the dairy matrix, being on average $30,38,24$, and $21 \%$ for milk, yogurt, fresh cheese, and aged cheese, respectively [82].

Despite model cheeses not being optimal for vitamin $\mathrm{D}_{3}$ supply, gel-like matrices such as cheese can be modulated depending on formulation and processing conditions, leading to different behavior during digestion. In fact, in cheese matrices, aggregated casein micelles create a microstructural network with entrapped solid fat globules and serum, and their digestion is directly related to cheese microstructure [83]. Detailed information on the impact of gel structure on vitamin $\mathrm{D}_{3^{\prime}} \mathrm{s}$ bioaccessibility was obtained by comparing model acid-coagulated fresh cheeses varying in protein-to-fat ratios $(0.9,1.3,1.7$, and 2) and in the particle size of the cheese milk emulsion due to different homogenization pressures applied (17-150 MPa) [32]. To prepare these model cheeses, milk was fortified by adding free vitamin $\mathrm{D}_{3}$ previously dissolved in ethanol and then in melted anhydrous milk fat. Interestingly, vitamin $\mathrm{D}_{3^{\prime}}$ s bioaccessibility decreased from 64.51 to $41.56 \%$ when the protein-to-fat ratio was increased from 0.9 to 2 . An increase in milk homogenization pressure from 17 to $150 \mathrm{MPa}$ also caused a decrease in vitamin $\mathrm{D}_{3^{\prime}} \mathrm{s}$ bioaccessibility from 64.51 to $27.17 \%$. Both increase in protein content and increase in homogenization pressure caused the formation of a stronger protein network that entrapped smaller fat particles, 
leading to the hypothesis that changes in the gel microstructure were responsible for the lower release of fat-soluble components during digestion.

Table 4. Bioaccessibility of vitamin D from various fortified foods.

\begin{tabular}{|c|c|c|c|}
\hline Fortified Food & $\begin{array}{l}\text { Vitamin D Content } \\
(\mu \mathrm{g} / 100 \mathrm{~g})\end{array}$ & $\begin{array}{l}\text { Bioaccessibility } \\
(\%)\end{array}$ & Ref \\
\hline $\begin{array}{l}\text { Yeast vitamin } \mathrm{D}_{2} \\
\text { in white wheat bread }\end{array}$ & 4.67 & 15 & \multirow{3}{*}{ [30] } \\
\hline $\begin{array}{l}\text { Yeast vitamin } \mathrm{D}_{2} \\
\text { in whole wheat bread }\end{array}$ & 4.87 & 9.9 & \\
\hline $\begin{array}{l}\text { Free vitamin } \mathrm{D}_{2} \text { (control) } \\
\text { in whole wheat bread }\end{array}$ & 3.9 & 38 & \\
\hline $\begin{array}{l}\text { Free vitamin } \mathrm{D}_{3} \\
\text { in skimmed milk }\end{array}$ & 1.12 & 32 & \multirow{4}{*}[30]{} \\
\hline $\begin{array}{c}\text { Free vitamin } \mathrm{D}_{3} \\
\text { in partially defatted milk (2\% fat) }\end{array}$ & 1.02 & 70 & \\
\hline $\begin{array}{c}\text { Free vitamin } \mathrm{D}_{3} \\
\text { in whole milk }(3.25 \% \text { fat })\end{array}$ & 1.28 & 53 & \\
\hline $\begin{array}{c}\text { Free vitamin } \mathrm{D}_{3} \\
\text { in infant powder formula (4\% fat) }\end{array}$ & 10.94 & 54 & \\
\hline $\begin{array}{l}\text { Natural vitamin } \mathrm{D}_{3} \\
\text { in whole milk }\end{array}$ & 3.97 & 30 & \multirow{4}{*}{ [82] } \\
\hline $\begin{array}{l}\text { Natural vitamin } \mathrm{D}_{3} \\
\text { in yogurt }\end{array}$ & 3.1 & 38 & \\
\hline $\begin{array}{l}\text { Natural vitamin } \mathrm{D}_{3} \\
\text { in fresh cheese }\end{array}$ & 13.8 & 24 & \\
\hline $\begin{array}{l}\text { Natural vitamin } D_{3} \\
\text { in aged cheese }\end{array}$ & 21.7 & 21 & \\
\hline $\begin{array}{c}\text { Free vitamin } \mathrm{D}_{3} \\
\text { in cheese (17 MPa, protein/fat ratio 0.9), }\end{array}$ & 488 & 64 & \multirow{3}{*}{ [32] } \\
\hline $\begin{array}{c}\text { Free vitamin } \mathrm{D}_{3} \\
\text { in cheese (17 MPa, protein/fat ratio } 2) \text {, }\end{array}$ & 498 & 51 & \\
\hline $\begin{array}{c}\text { Free vitamin } \mathrm{D}_{3} \\
\text { in cheese }(150 \mathrm{MPa} \text {, protein / fat ratio } 2)\end{array}$ & 499 & 27 & \\
\hline $\begin{array}{c}\text { Vitamin } \mathrm{D}_{3} \text { in } \mathrm{W}_{1} / \mathrm{O} / \mathrm{W}_{2} \text { emulsion } \\
\text { in high-protein yogurt }\end{array}$ & 10 & 100 & \multirow[b]{2}{*}{ [49] } \\
\hline $\begin{array}{c}\text { Vitamin } \mathrm{D}_{3} \text { in } \mathrm{W}_{1} / \mathrm{O} / \mathrm{W}_{2} \text { emulsion } \\
\text { in high-protein yogurt }\end{array}$ & 10 & 100 & \\
\hline $\begin{array}{l}\text { Vitamin } \mathrm{D}_{3} \text { nanoemulsion } \\
\text { in oat milk or almond milk }\end{array}$ & 400 & 20 & [46] \\
\hline $\begin{array}{l}\text { Vitamin } \mathrm{D}_{3} \mathrm{~W} / \mathrm{O} \text { nanoemulsion } \\
\text { in almond milk }+\mathrm{CaCl}_{2} \text { or } \mathrm{CaCO}_{3}\end{array}$ & nd & $<20$ & [47] \\
\hline $\begin{array}{c}\text { Vitamin } \mathrm{D}_{3} \text { in refined olive oil } \\
\text { in beef }\end{array}$ & 16.7 & 5 & \multirow{2}{*}{ [33] } \\
\hline $\begin{array}{l}\text { Vitamin } \mathrm{D}_{3} \text { in refined olive oil } \\
\text { in semolina or in chickpeas }\end{array}$ & 3.0 & 25 & \\
\hline $\begin{array}{l}\text { Vitamin } \mathrm{D}_{3} \text { in canola oil } \\
\text { in brownies }\end{array}$ & nd & 65.2 & \multirow[b]{2}{*}{ [84] } \\
\hline $\begin{array}{l}\text { Oily vitamin } \mathrm{D}_{3} \text { in canola oil + } \\
\text { tert-butylhydroquinone } \\
\text { in brownies }\end{array}$ & nd & 98 & \\
\hline $\begin{array}{l}\text { Vitamin } \mathrm{D}_{3} \text { in zein nanocapsules } \\
\text { in a fruit (Acca sellowiana) jelly }\end{array}$ & 159 & 81 & [52] \\
\hline
\end{tabular}

nd: not reported.

The concept of combining vitamin $\mathrm{D}_{3}$ fortification of food with increase in protein content is particularly relevant to address the nutritional demands of older people [85]. Consistent with this aim, a high-protein (10\%) yogurt fortified with a $\mathrm{W}_{1} / \mathrm{O} / \mathrm{W}_{2}$ double emulsion containing berry polyphenols and water-soluble vitamins $\left(C, B_{9}\right.$ and $\left.B_{12}\right)$ in the inner water phase and lipid-soluble vitamins (A and D) in the oil phase was devel- 
oped [49]. The ingredients used to formulate the double emulsion were refined rapeseed oil, polyglycerol polyricinoleate, milk protein concentrate, sodium chloride, and sucrose. Free vitamin $\mathrm{D}_{3}$ was also added directly to the oil as a control. The results showed that the fortification of yogurt with vitamins loaded into the double emulsion did not hinder the release of vitamins during digestion, which was 100\% for both the encapsulated vitamin $\mathrm{D}_{3}$ and the free oily vitamin $\mathrm{D}_{3}$ at the end of the intestinal phase. However, the kinetics of digestion were different since the release of oily vitamin $\mathrm{D}_{3}$ at the end of the gastric phase was considerably higher compared to the release of encapsulated vitamin $\mathrm{D}_{3}$.

Plant-based "milk" types were investigated as matrices to incorporate various forms of vitamin $\mathrm{D}_{3}$-namely, vitamin $\mathrm{D}_{3}$ in $\mathrm{O} / \mathrm{W}$ nanoemulsion made with corn oil, and vitamin $\mathrm{D}_{3}$ nanoemulsion with added $\mathrm{TiO}_{2}$ or nanocellulose powders [46]. The vitamin bioaccessibility was around $20 \%$ in all of the fortified plant-based milks, indicating that neither type of nanoparticle (inorganic or organic) had a major impact on the bioaccessibility of vitamin $\mathrm{D}$. The reasons for the observed low bioaccessibility were hypothesized to be either a saturation of the mixed micelles or the aggregation and precipitation of the majority of vitamin-loaded mixed micelles due to some of the constituents in the plant-based milks. In a subsequent study, vitamin $\mathrm{D}_{3}$ was encapsulated in a nanoemulsion made with corn oil quillaja saponin before addition to almond milk, but this approach also resulted in only $20 \%$ vitamin bioaccessibility [47]. Moreover, since plant-based milks are deficient in calcium, either soluble $\left(\mathrm{CaCl}_{2}\right)$ or insoluble $\left(\mathrm{CaCO}_{3}\right)$ calcium salts were added to vitamin- $\mathrm{D}_{3}$-fortified almond milk, but the addition of calcium further reduced vitamin D's bioaccessibility [47]. A negative effect of $\mathrm{Ca}^{++}$on vitamin $\mathrm{D}_{3^{\prime}}$ s bioaccessibility had also been observed in a previous study, in which $\mathrm{Ca}^{++}$and vitamin $\mathrm{D}_{3}$ had been co-encapsulated in different $\mathrm{W}_{1} / \mathrm{O} / \mathrm{W}_{2}$ double emulsions. This effect was attributed to insoluble calcium soap formation in the small intestine step of digestion [86].

In meat, semolina, and chickpeas, vitamin $\mathrm{D}_{3}$ was applied after solubilization in refined olive oil, and the resulting bioaccessibility was 5, 25, and 25\%, respectively. Low bioaccessibility in meat was attributed to intense oxidation during digestion [33]. Semolina and chickpea antioxidants protected vitamin $\mathrm{D}_{3}$ from oxidative degradation; however, despite high vitamin $\mathrm{D}_{3}$ content being found in the intestinal digesta of these meals, the incorporation of vitamin $\mathrm{D}_{3}$ into the mixed micelles was hindered by tannins, fibers, and saponins [33]. The decrease in vitamin $\mathrm{D}_{3}$ bioaccessibility due to the occurrence of oxidation during digestion has also been supported by a previous study, which reported increased bioaccessibility of vitamin $\mathrm{D}_{3}$ in brownies fortified with both vitamin $\mathrm{D}_{3}$ and tert-butylhydroquinone, compared to a control fortified with vitamin $\mathrm{D}_{3}$ alone. On the other hand, $\alpha$-tocopherol and butylated hydroxytoluene were not efficient [84].

A fruit jelly model proved to be an effective matrix for vitamin $D_{3}$ fortification. In fact, vitamin $\mathrm{D}_{3}$ encapsulated in zein nanoparticles was used as an ingredient in jelly, which presented $81 \%$ bioaccessibility for vitamin $\mathrm{D}_{3}$ [52].

\section{Conclusions and Future Perspectives}

For the effective delivery of vitamin D through fortified foods, a careful formulation into nano- and micro-structures to be dispersed in the food matrix is a promising strategy. Due to the complexity and diversity of the food structures, the application of different encapsulation strategies could better address the need to develop carrier systems that simultaneously provide long-term chemical and physical stability, bioaccessibility and, ultimately, in vivo functionality of the vitamin.

However, information on vitamin D's stability during processing is still fairly correlated with the form in which the vitamin was added to the food matrix. Moreover, knowledge concerning vitamin D's stability during processing is limited to only a few processing steps, while a better understanding of the kinetic parameters of vitamin $\mathrm{D}_{3}$ and $\mathrm{D}_{2}$ degradation-i.e., rate constant and activation energy, could allow the prediction of vitamin D content in fortified foods and, thus, enable process optimization under industrial conditions. 
Bioaccessibility studies provided insight into the potential efficacy of various vitaminD-fortified foods, addressing the role of lipids, proteins, fibers, antioxidants, and $\mathrm{Ca}^{++}$ ions. The main challenge in future studies will be to acquire advanced knowledge of the interactions between vitamin D and specific molecules-especially single proteins and fibers-in order to take advantages from possible synergism. Moreover, validated in vitro models to assess vitamin D's bioaccessibility in various target populations-such as the elderly, obese subjects, and subjects affected by malabsorption diseases-could assist a proper fortified food design, since a large variability in response to vitamin D supplementation has also been observed among individuals.

Author Contributions: Conceptualization, V.L.; methodology, V.L. and P.D.; investigation, data curation, original draft preparation, V.L., P.D. and L.P.; writing-review and editing, V.L., L.P. and P.D.; supervision, V.L. All authors have read and agreed to the published version of the manuscript.

Funding: This research received no external funding.

Acknowledgments: The authors are grateful to their colleague John A. Hogenboom for kindly revising the manuscript.

Conflicts of Interest: The authors declare no conflict of interest.

\section{References}

1. Milešević, J.; Samaniego, L.; Kiely, M.; Glibetić, M.; Roe, M.; Finglas, P. Specialized food composition dataset for vitamin D content in foods based on European standards: Application to dietary intake assessment. Food Chem. 2018, 240, 544-549. [CrossRef] [PubMed]

2. Grant, W.B.; Anouti, F.A.; Moukayed, M. Targeted 25-hydroxyvitamin D concentration measurements and vitamin $\mathrm{D}_{3}$ supplementation can have important patient and public health benefits. Eur. J. Clin. Nutr. 2020, 74, 366-376. [CrossRef] [PubMed]

3. Holick, M.F.; Chen, T.C. Vitamin D deficiency: A worldwide problem with health consequences. Am. J. Clin. Nutr. 2008, 87, 1080S-1086S. [CrossRef] [PubMed]

4. Biancuzzo, R.M.; Young, A.; Bibuld, D.; Cai, M.H.; Winter, M.R.; Klein, E.K.; Ameri, A.; Reitz, R.; Salameh, W.; Chen, T.C.; et al. Fortification of orange juice with vitamin $\mathrm{D}_{2}$ or vitamin $\mathrm{D}_{3}$ is as effective as an oral supplement in maintaining vitamin $\mathrm{D}$ status in adults. Am. J. Clin. Nutr. 2010,91,1621-1626. [CrossRef]

5. Khazai, N.B.; Judd, S.E.; Jeng, L.; Wiolfenden, L.L.; Stecenko, A.; Ziegler, T.R.; Tangpricha, V. Treatment and prevention of vitamin D insufficiency in cystic fibrosis patients: Comparative efficacy of ergocalciferol, cholecalciferol, and UV light. J. Clin. Endocr. Metab. 2009, 94, 2037-2043. [CrossRef]

6. Romagnoli, E.; Mascia, M.L.; Cipriani, C.; Fassino, V.; Mazzei, F.; D’Erasmo, E.; Carnevale, V.; Scillitani, A.; Minisola, S. Short and long-term variations in serum calciotropic hormones after a single very large dose of ergocalciferol (vitamin $\mathrm{D}_{2}$ ) or cholecalciferol (vitamin $\mathrm{D}_{3}$ ) in the elderly. J. Clin. Endocr. Metab. 2008, 93, 3015-3020. [CrossRef]

7. Jakobsen, J.; Andersen, E.A.W.; Christensen, T.; Andersen, R.; Bügel, S. Vitamin D vitamers affect vitamin D status differently in young healthy males. Nutrients 2018, 10, 12. [CrossRef]

8. Holick, M.F.; Biancuzzo, R.M.; Chen, T.C.; Klein, E.K.; Young, A.; Bibuld, D.; Reitz, R.; Salameh, W.; Ameri, A.; Tannenbaum, A.D. Vitamin $\mathrm{D}_{2}$ is as effective as vitamin $\mathrm{D}_{3}$ in maintaining circulating concentrations of 25-hydroxyvitamin D. J. Clin. Endocr. Metab. 2008, 93, 677-681. [CrossRef]

9. Holick, M.F. The vitamin D deficiency pandemic: Approaches for diagnosis, treatment and prevention. Rev. Endocr. Metab. Disord. 2017, 18, 153-165. [CrossRef]

10. Holick, M.F.; Binkley, N.C.; Bischoff-Ferrari, H.A.; Gordon, C.M.; Hanley, D.A.; Heaney, R.P.; Murad, M.H.; Weaver, C.M. Evaluation, treatment, and prevention of vitamin D deficiency: An Endocrine Society clinical practice guideline. J. Clin. Endocrinol. Metab. 2011, 96, 1911-1930. [CrossRef]

11. Ekwaru, J.P.; Zwicker, J.D.; Holick, M.F.; Giovannucci, E.; Veugelers, P.J. The importance of body weight for the dose response relationship of oral vitamin D supplementation and serum 25-hydroxyvitamin D in healthy volunteers. PLoS ONE 2014, 9, 111265. [CrossRef]

12. Cashman, K.D.; Kiely, M.E.; Andersen, R.; Grønborg, I.M.; Madsen, K.H.; Nissen, J.; Tetens, I.; Tripkovic, L.; Lanham-New, S.A.; Toxqui, L.; et al. Individual participant data (IPD)-level meta-analysis of randomized controlled trials with vitamin D-fortified foods to estimate Dietary Reference Values for vitamin D. Eur. J. Nutr. 2021, 60, 939-959. [CrossRef]

13. Roman Viñas, B.; Ribas Barba, L.; Ngo, J.; Gurinovic, M.; Novakovic, R.; Cavelaars, A.; de Groot, L.C.P.G.M.; van't Veer, P.; Matthys, C.; Serra Majem, L. Projected prevalence of inadequate nutrient intakes in Europe. Ann. Nutr. Metab. 2011, 59, 84-95. [CrossRef]

14. Moore, C.E.; Radcliffe, J.D.; Liu, Y. Vitamin D intakes of adults differ by income, gender and race/ethnicity in the USA, 2007 to 2010. Public Health Nutr. 2013, 17, 1-8. [CrossRef] 
15. O'Mahony, L.; Stepien, M.; Gibney, M.J.; Nugent, A.P.; Brennan, L. The potential role of vitamin D enhanced foods in improving vitamin D status. Nutrients 2011, 3, 1023-1041. [CrossRef]

16. Natri, A.M.; Salo, P.; Vikstedt, T.; Palssa, A.; Huttunen, M.; Karkkainen, M.U.; Salovaara, H.; Piironen, V.; Jakobsen, J.; LambergAllardt, C.J. Bread fortified with cholecalciferol increases the serum 25-hydroxyvitamin D concentration in women as effectively as a cholecalciferol supplement. J. Nutr. 2006, 136, 123-127. [CrossRef]

17. Itkonen, S.T.; Skaffari, E.; Saaristo, P.; Saarnio, E.M.; Erkkola, M.; Jakobsen, J.; Cashman, K.D.; Lamberg-Allardt, C. Effects of vitamin $\mathrm{D}_{2}$-fortified bread v. supplementation with vitamin $\mathrm{D}_{2}$ or $\mathrm{D}_{3}$ on serum 25-hydroxyvitamin $\mathrm{D}$ metabolites: An 8-week randomised-controlled trial in young adult Finnish women. Br. J. Nutr. 2016, 115, 1232-1239. [CrossRef]

18. Urbain, P.; Singler, F.; Ihorst, G.; Biesalski, H.K.; Bertz, H. Bioavailability of vitamin $\mathrm{D}_{2}$ from UV-B-irradiated button mushrooms in healthy adults deficient in serum 25 hydroxyvitamin D: A randomized controlled trial. Eur. J. Clin. Nutr. 2011, 65, 965-971. [CrossRef]

19. Daly, R.M.; Brown, M.; Bass, S.; Kukuljan, S.; Nowson, C. Calcium- and vitamin $\mathrm{D}_{3}$-fortified milk reduces bone loss at clinically relevant skeletal sites in older men: A 2-year randomized controlled trial. J. Bone Miner. Res. 2006, 21, 397-405. [CrossRef]

20. Neyestani, T.R.; Hajifaraji, M.; Omidvar, N.; Nikooyeh, B.; Eshraghian, M.R.; Shariatzadeh, N.; Kalayi, A.; Khalaji, N.; Zahedirad, M.; Abtahi, M.; et al. Calcium-vitamin D-fortified milk is as effective on circulating bone biomarkers a fortified juice and supplement but has less acceptance: A randomised controlled school-based trial. J. Human Nutr. Diet. 2014, 27, 606-616. [CrossRef]

21. Johnson, J.L.; Mistry, V.V.; Vukovich, M.D.; Hogie-Lorenzen, T.; Hollis, B.W.; Specker, B.L. Bioavailability of vitamin D from fortified process cheese and effects on vitamin D status in the elderly. J. Dairy Sci. 2005, 88, 2295-2301. [CrossRef]

22. Wagner, D.; Sidhom, G.; Whiting, S.J.; Rousseau, D.; Vieth, R. The bioavailability of vitamin D from fortified cheeses and supplements is equivalent in adults. J. Nutr. 2008, 138, 1365-1371. [CrossRef] [PubMed]

23. Nikooyeh, B.; Neyestani, T.R.; Farvid, M.; Alavi-Majd, H.; Houshiarrad, A.; Kalayi, A.; Shariatzadeh, N.; Gharavi, A.; Heravifard S.; Tayebinejad, N.; et al. Daily consumption of vitamin D- or vitamin D+ calcium-fortified yogurt drink improved glycemic control in patients with type 2 diabetes: A randomized clinical trial. Am. J. Clin. Nutr. 2011, 93, 764-771. [CrossRef] [PubMed]

24. Beauchet, O.; Launay, C.P.; Galery, K.; Vilcocq, C.; Dontot-Payen, F.; Rousseau, B.; Benoit, V.; Allali, G. Effects of vitamin $\mathrm{D}$ and Calcium fortified yogurts on gait, cognitive performances, and serum 25-hydroxyvitamin $\mathrm{D}$ concentrations in older community-dwelling females: Results from the GAit, MEmory, Dietary and vitamin D (GAME-D2) randomized controlled trial. Nutrients 2019, 11, 2880. [CrossRef]

25. Mostafaia, R.; Nachvakc, S.M.; Mohammadi, R.; Rocha, R.S.; da Silva, M.C.; Esmerinod, E.A.; Nascimento, K.O.; Cruz, A.G.; Mortazavian, A.M. Effects of vitamin D-fortified yogurt in comparison to oral vitamin D supplement on hyperlipidemia in pre-diabetic patients: A randomized clinical trial. J. Func. Foods 2019, 52, 116-120. [CrossRef]

26. Levinson, Y.; Ish-Shalom, S.; Segal, E.; Livney, Y.D. Bioavailability, rheology and sensory evaluation of fat-free yogurt enriched with $\mathrm{VD}_{3}$ encapsulated in re-assembled casein micelles. Food Funct. 2016, 7, 1477-1482. [CrossRef]

27. Indyk, H.; Littlejohn, V.; Woollard, D. Stability of vitamin $\mathrm{D}_{3}$ during spray-drying of milk. Food Chem. 1996, 57, 283-286. [CrossRef]

28. Jakobsen, J.; Knuthsen, P. Stability of vitamin D in foodstuffs during cooking. Food Chem. 2014, 148, 170-175. [CrossRef]

29. Hemery, Y.M.; Fontan, L.; Moench-Pfanner, R.; Laillou, A.; Berger, A.; Renaud, J.C.; Avallone, S. Influence of light exposure and oxidative status on the stability of vitamins $\mathrm{A}$ and $\mathrm{D}_{3}$ during the storage of fortified soybean oil. Food Chem. 2015, 184, 90-98. [CrossRef]

30. Lipkie, T.E.; Ferruzzi, M.G.; Weaver, C.W. Low bioaccessibility of vitamin $\mathrm{D}_{2}$ from yeast fortified bread compared to crystalline $\mathrm{D}_{2}$ bread and $\mathrm{D}_{3}$ from fluid milks. Food Funct. 2016, 7, 4589-4596. [CrossRef]

31. Ložnjak, P.; Jakobsen, J. Stability of vitamin $\mathrm{D}_{3}$ and vitamin $\mathrm{D}_{2}$ in oil, fish and mushrooms after household cooking. Food Chem. 2018, 254, 144-149. [CrossRef]

32. Castaneda, N.; Lee, Y. Microstructure of a model fresh cheese and bioaccessibility of vitamin $\mathrm{D}_{3}$ using in vitro digestion. Gels 2019, 5, 16. [CrossRef]

33. Antoine, T.; Icard-Verniere, C.; Scorrano, G.; Salhi, A.; Halimi, C.; George, S.; Carriere, F.; Mouquet-Rivier, C.; Reboul, E. Evaluation of vitamin D bioaccessibility and mineral solubility from test meals containing meat and/or cereals and/or pulses using in vitro digestion. Food Chem. 2021, 347, 128621. [CrossRef]

34. Kazmi, S.A.; Vieth, R.; Rosseau, D. Vitamin $\mathrm{D}_{3}$ fortification and quantification in processed dairy products. Int. Dairy J. 2007, 17, 753-759. [CrossRef]

35. Wagner, D.; Rousseau, E.; Sidhom, G.; Pouliot, M.; Audet, P.; Vieth, R. Vitamin $\mathrm{D}_{3}$ fortification, quantification, and long-term stability in Cheddar and low-fat cheeses. J. Agric. Food Chem. 2008, 56, 7964-7969. [CrossRef]

36. Salvia-Trujillo, L.; Fumiaki, L.B.; Park, J.; McClements, D.J. The influence of lipid droplet size on the oral bioavailability of vitamin $\mathrm{D}_{2}$ encapsulated in emulsions: An in vitro and in vivo study. Food Funct. 2017, 8, 767-777. [CrossRef]

37. Hanson, A.L.; Metzger, L.E. Evaluation of increased vitamin D fortification in high-temperature, short-time-processed $2 \%$ milk, UHT-processed 2\% fat chocolate milk, and low-fat strawberry yogurt. J. Dairy Sci. 2010, 93, 801-807. [CrossRef]

38. Jafari, T.; Askari, G.; Mirlohi, M.; Javanmard, S.H.; Faghihimani, E.; Fallah, A.A. Stability of Vitamin $\mathrm{D}_{3}$ in fortified yoghurt and yoghurt drink (Doogh). Adv. Biomed. Res. 2016, 5, 52. [CrossRef] 
39. Kaushik, R.; Sachdeva, B.; Arora, S. Vitamin $\mathrm{D}_{2}$ stability in milk during processing, packaging and storage. LWT-Food Sci. Technol. 2014, 56, 421-442. [CrossRef]

40. Lavelli, V. Circular food supply chains-Impact on value addition and safety. Trends Food Sci. Technol. 2021, 114, 323-332. [CrossRef]

41. McClements, D.J.; Decker, E.A.; Park, Y.; Weiss, J. Structural design principles for delivery of bioactive components in nutraceuticals and functional foods. Crit. Rev. Food Sci. Nutr. 2009, 49, 577-606. [CrossRef] [PubMed]

42. Stratulat, I.; Britten, M.; Salmieri, S.; Fustier, P.; St-Gelais, D.; Champagne, C.P.; Lacroix, M. Enrichment of cheese with bioactive lipophilic compounds. J. Func. Foods 2014, 6, 48-59. [CrossRef]

43. Stratulat, I.; Britten, M.; Salmieri, S.; Fustier, P.; St-Gelais, D.; Champagne, C.P.; Lacroix, M. Enrichment of cheese with vitamin $D_{3}$ and vegetable omega-3. J. Func. Foods 2015, 13, 300-307. [CrossRef]

44. Maurya, V.K.; Aggarwal, M. Factors influencing the absorption of vitamin D in GIT: An overview. J. Food Sci. Technol. 2017, 54, 3753-3765. [CrossRef]

45. Maurya, V.K.; Aggarwal, M. Impact of Aqueous/ethanolic goji Berry (Lycium barbarum) fruit extract supplementation on vitamin D stability in yoghurt. Int. J. Curr. Microbiol. App. Sci. 2017, 6, 2016-2029. [CrossRef]

46. Zhou, H.; Liu, J.; Dai, T.; Mundo, J.L.M.; Tan, Y.; Bai, L.; McClements, D.J. The gastrointestinal fate of inorganic and organic nanoparticles in vitamin D-fortified plant-based milks. Food Hydrocoll. 2021, 112, 106310. [CrossRef]

47. Zhou, H.; Zheng, B.; Zhang, Z.; Zhang, R.; He, L.; McClements, D.J. Fortification of plant-based milk with calcium may reduce vitamin D bioaccessibility: An in vitro digestion study. J. Agric. Food Chem. 2021, 69, 4223-4233. [CrossRef]

48. Kersien, M.; Jasutien, I.; Eisinait, V.; Venskutonis, P.R.; Leskauskait, D. Designing multiple bioactives loaded emulsions for the formulations for diets of elderly. Food Funct. 2020, 11, 2195-2207. [CrossRef]

49. Kersien, M.; Jasutien, I.; Eisinait, V.; Pukalskien, M.; Venskutonis, P.R.; Damulevicien, G.; Knasiene, J.; Lesauskait, V.; Leskauskait, D. Development of a high-protein yoghurt-type product enriched with bioactive compounds for the elderly. LWT-Food Sci. Technol. 2020, 131, 109820. [CrossRef]

50. Didar, Z. Inclusion of vitamin $\mathrm{D}_{3}$ (free or liposome) into white chocolate and an investigation of its stability during storage. J. Food Process. Preserv. 2021, 45, 15231. [CrossRef]

51. Syama, M.A.; Arora, S.; Gupta, C.; Sharma, A.; Sharma, V. Enhancement of vitamin $\mathrm{D}_{2}$ stability in fortified milk during light exposure and commercial heat treatments by complexation with milk proteins. Food Biosci. 2019, 29, 17-23. [CrossRef]

52. Zapelini de Melo, A.P.; Gonçalves da Rosa, C.; Montanheiro Noronha, C.; Heck Machado, M.; Sganzerla, W.G.; da Cunha Bellinati, V.N.; Verruck, S.; Schwinden Prudencio, E.; Manique Barreto, P.L. Nanoencapsulation of vitamin $\mathrm{D}_{3}$ and fortification in an experimental jelly model of Acca sellowiana: Bioaccessibility in a simulated gastrointestinal system. LWT-Food Sci. Technol. 2021, 145, 111287. [CrossRef]

53. Ozturk, B. Nanoemulsions for food fortification with lipophilic vitamins: Production challenges, stability, and bioavailability. Eur. J. Lipid Sci. Technol. 2017, 119, 1500539. [CrossRef]

54. Muschiolik, G.; Dickinson, E. Double emulsions relevant to food systems: Preparation, stability, and applications. Compr. Rev. Food Sci. Food Saf. 2017, 16, 532-555. [CrossRef]

55. Taylor, T.M.; Weiss, J.; Davidson, P.M.; Bruce, B.D. Liposomal nanocapsules in food science and agriculture. Crit. Rev. Food Sci. Nutr. 2005, 45, 587-605. [CrossRef]

56. Taylor, T.M.; Morris, R.M. Thermal analysis of phase transition behavior in liposomes. Thermochim. Acta 1995, $248,289-301$. [CrossRef]

57. Banville, C.; Vuillemard, J.C.; Lacroix, C. Comparison of different methods for fortifying Cheddar cheese with vitamin D. Int. Dairy J. 2000, 10, 375-382. [CrossRef]

58. Tang, C.H. Assembly of food proteins for nano-encapsulation and delivery of nutraceuticals (a mini-review). Food Hydrocoll. 2021, 117, 106710. [CrossRef]

59. Diarrassouba, F.; Garrait, G.; Remondetto, G.; Alvarez, P.; Beyssac, E.; Subirade, M. Improved bioavailability of vitamin $D_{3}$ using a $\beta$-lactoglobulin-based coagulum. Food Chem. 2015, 172, 361-367. [CrossRef]

60. Abbasi, A.; Emam-Djomeh, Z.; Mousavi, M.A.E.; Davoodi, D. Stability of vitamin $\mathrm{D}_{3}$ encapsulated in nanoparticles of whey protein isolate. Food Chem. 2014, 143, 379-383. [CrossRef]

61. Loewen, A.; Chan, B.; Li-Chan, E.C. Optimization of vitamins A and $\mathrm{D}_{3}$ loading in re-assembled casein micelles and effect of loading on stability of vitamin $\mathrm{D}_{3}$ during storage. Food Chem. 2018, 240, 472-481. [CrossRef]

62. Menéndez-Aguirre, O.; Kessler, A.; Stuetz, W.; Grune, T.; Weiss, J.; Hinrichs, J. Increased loading of vitamin $\mathrm{D}_{2}$ in reassembled casein micelles with temperature-modulated high pressure treatment. Food Res. Int. 2014, 64, 74-80. [CrossRef]

63. Levinson, Y.; Israeli-Lev, G.; Livney, Y.D. Soybean $\beta$-conglycinin nanoparticles for delivery of hydrophobic nutraceuticals. Food Biophys. 2014, 9, 332-340. [CrossRef]

64. Jin, X.; Yang, X.; Yang, L.; Liu, Z.L.; Zhang, F. Autoxidation of isotachysterol. Tetrahedron 2004, 60, 2881-2888. [CrossRef]

65. Tsai, S.-Y.; Lin, H.-Y.; Hong, W.-P.; Lin, C.-P. Evaluation of preliminary causes for vitamin D series degradation via DSC and HPLC analyses. J. Therm. Anal. Calorim. 2017, 130, 1357-1369. [CrossRef]

66. Mahmoodani, F.; Perera, C.O.; Fedrizzi, B.; Abernethy, G.; Chen, H. Degradation studies of cholecalciferol (vitamin $\mathrm{D}_{3}$ ) using HPLC-DAD, UHPLC-MS/MS and chemical derivatization. Food Chem. 2017, 219, 373-381. [CrossRef] 
67. Scott, K.; Latshaw, J. Effects of commercial processing on the fat-soluble vitamin content of menhaden fish oil. J. Am. Oil Chem. Soc. 1991, 68, 234-236. [CrossRef]

68. Bajaj, S.R.; Singhal, R.S. Fortification of wheat flour and oil with vitamins $\mathrm{B}_{12}$ and $\mathrm{D}_{3}$ : Effect of processing and storage. J. Food Compos. Anal. 2021, 96, 103703. [CrossRef]

69. Corey, M.E.; Kerr, W.L.; Mulligan, J.H.; Lavelli, V. Phytochemical stability in dried apple and green tea functional products as related to moisture properties. LWT_Food Sci. Technol. 2011, 44, 67-74. [CrossRef]

70. Lavelli, V.; Proserpio, C.; Gallotti, F.; Laureati, M.; Pagliarini, E. Circular reuse of bio-resources: The role of Pleurotus spp. in the development of functional foods. Food Funct. 2018, 9, 1353-1372. [CrossRef]

71. Pedrali, D.; Gallotti, F.; Proserpio, C.; Pagliarini, E.; Lavelli, V. Kinetic study of vitamin $\mathrm{D}_{2}$ degradation in mushroom powder to improve its applications in fortified foods. LWT_Food Sci. Technol. 2020, 125, 109248. [CrossRef]

72. Zhu, J.; Sevilla, M.D. Kinetic analysis of free-radical reactions in the low temperature autoxidation of triglycerides. J. Phys. Chem. 1990, 94, 1447-1452. [CrossRef]

73. Salemi, S.; Saedisomeolia, A.; Azimi, F.; Zolfigol, S.; Mohajerani, E.; Mohammadi, M.; Yaseri, M. Optimizing the production of vitamin D in white button mushrooms (Agaricus bisporus) using ultraviolet radiation and measurement of its stability. LWT-Food Sci. Technol. 2021, 137, 110401. [CrossRef] [PubMed]

74. Mattila, P.; Ronkainen, R.; Lehikoinen, K.; Piironen, V. Effect of household cooking on the vitamin D content in fish, eggs, and wild mushrooms. J. Food Composit. Anal. 1999, 12, 153-160. [CrossRef]

75. Renken, J.D.; Warthesen, J.J. Vitamin D stability in milk. J. Food Sci. 1993, 58, 552-556. [CrossRef]

76. Limbo, S.; Pellegrino, L.; D'Incecco, P.; Gobbi, S.; Rosi, V.; Fracassetti, D. Storage of pasteurized milk in clear PET bottles combined with light exposure on a retail display case: A possible strategy to define the shelf life and support a recyclable packaging. Food Chem. 2020, 329, 127116. [CrossRef]

77. Forrest, S.A.; Yada, R.Y.; Rousseau, D. Interactions of vitamin $\mathrm{D}_{3}$ with bovine $\beta$-lactoglobulin A and $\beta$-casein. J. Agricul. Food Chem. 2005, 53, 8003-8009. [CrossRef]

78. Delavari, B.; Saboury, A.A.; Atri, M.S.; Ghasemi, A.; Bigdeli, B.; Khammari, A.; Goliaei, B. Alpha-lactalbumin: A new carrier for vitamin $\mathrm{D}_{3}$ food enrichment. Food Hydrocoll. 2015, 45, 124-131. [CrossRef]

79. Borel, P.; Caillaud, D.; Cano, N. Vitamin D bioavailability: State of the art. Crit. Rev. Food Sci. Nutr. 2015, 55, 1193-1205. [CrossRef]

80. Tan, Y.; McClements, D.J. Improving the bioavailability of oil-soluble vitamins by optimizing food matrix effects: A. review. Food Chem. 2021, 348, 129148. [CrossRef]

81. Dima, C.; Assadpour, E.; Dima, S.; Jafari, S.M. Bioavailability of nutraceuticals: Role of the food matrix, processing conditions, the gastrointestinal tract, and nanodelivery systems. Compr. Rev. Food Sci. Food Saf. 2020, 19, 954-994. [CrossRef] [PubMed]

82. Hernandez-Olivas, E.; Munoz-Pina, S.; Sanchez-Garcia, J.; Andres, A.; Heredia, A. Understanding the role of food matrix on the digestibility of dairy products under elderly gastrointestinal conditions. Food Res. Int. 2020, 137, 109454. [CrossRef] [PubMed]

83. Lamothe, S.; Corbeil, M.-M.; Turgeon, S.L.; Britten, M. Influence of cheese matrix on lipid digestion in a simulated gastro-intestinal environment. Food Funct. 2012, 3, 724-731. [CrossRef] [PubMed]

84. Goebel, S.; Avallone, S.; Detchewa, P.; Prasajak, P.; Sriwichai, W. Natural and synthetic antioxidants prevent the degradation of vitamin $\mathrm{D}_{3}$ fortification in canola oil during baking and in vitro digestion. Appl. Sci. Eng. Prog. 2021, 14, 247-258. [CrossRef]

85. Nowson, C.; O'Connell, S. Protein requirements and recommendations for older people: A review. Nutrients 2015, 7, 6874-6899. [CrossRef]

86. Dima, C.; Dima, S. Bioaccessibility study of calcium and vitamin $\mathrm{D}_{3}$ co-microencapsulated in water-in-oil-in-water double emulsions. Food Chem. 2020, 303, 125416. [CrossRef] 